\title{
A 600-MILLION-YEAR CARBONATE CLUMPED-ISOTOPE RECORD FROM THE SULTANATE OF OMAN
}

\author{
KRISTIN D. BERGMANN, ${ }^{1}$ SAID A.K. AL BALUSHI, ${ }^{2}$ TYLER J. MACKEY, ${ }^{1}$ JOHN P. GROTZINGER, ${ }^{3}$ AND JOHN M. EILER ${ }^{3}$ \\ ${ }^{1}$ Department of Earth, Atmospheric and Planetary Sciences, Massachusetts Institute of Technology, Cambridge, Massachusetts 02139, U.S.A. \\ ${ }^{2}$ Petroleum Development Oman, Mina Al-Fahal, Muscat, Sultanate of Oman \\ ${ }^{3}$ Division of Geological and Planetary Sciences, California Institute of Technology, Pasadena, California 91125, U.S.A. \\ e-mail:kdberg@mit.edu
}

\begin{abstract}
Carbonate clumped-isotope thermometry is a promising technique that has the potential to help decode the significance of the variability of both physical and geochemical compositions of ancient carbonate rocks. This study utilizes a 600-million-year record of marine carbonate rocks from the subsurface and surface of the Sultanate of Oman to explore how burial and exhumation affected the carbonate clumped-isotope thermometer. Samples span 6 km of burial depth, and include calcite and dolomite mineralogies and a range of carbonate rock textures. We find evidence for two broad patterns in the physical and geochemical behavior of carbonate rocks during burial. The first group of carbonates yield water $\delta^{18}$ Ovsmow compositions slightly enriched or equal to an expected "ice-free" seawater composition of $-\mathbf{1 . 2} \%$ and display good to fair textural preservation suggesting that cementation and lithification occurred within tens of meters of the sediment-water interface. Temperatures from the second group sit on the present-day geotherm, yield highly enriched water $\delta^{18} \mathbf{O}_{\text {VSMow }}$ compositions, and display fair to poor textural preservation. We find no evidence for solid-state reordering in paired analyses of calcites and dolomites. Our results

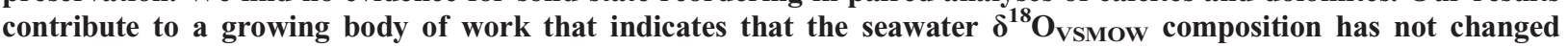
significantly over 600 Myr and was not $-6 \%$ in the Ediacaran.
\end{abstract}

\section{INTRODUCTION}

Marine carbonate fossils and rocks provide one of the best integrated records of ocean chemistry through time. However, the geochemistry of carbonate rocks records a series of overprinting events. During burial, shells, mud, and grains that precipitated from seawater experience dissolution to varying degrees, cements precipitate from pore fluids replacing or lithifying original components, and vein-filling and voidfilling carbonate cements precipitate from deeper-burial fluids. All of these processes leave textural evidence as well as chemical signatures and provide insight into the history of ancient rocks. The chemical metric that has arguably come closest to resolving questions concerning the postdepositional diagenetic path of a given carbonate component is the $\delta^{18} \mathrm{O}$ of the mineral (Urey 1947). The $\delta^{18} \mathrm{O}$ of a given carbonate component is dependent on both temperature, which changes with burial depth, and the composition of the precipitating fluid, which can change as pore fluids evolve when carbonate minerals are dissolved and reprecipitated. The $\delta^{18} \mathrm{O}$ of a bulk sample of carbonate rock then reflects all the primary and secondary events, and their respective temperature and fluid histories, that are recorded by the $\delta^{18} \mathrm{O}$ of various carbonate components (Brand 2004). This often-applied geochemical tool is imperfect in practice because it is impossible to deconvolve whether temperature and/or fluid composition is responsible for the observed $\delta^{18} \mathrm{O}$ of a lithified carbonate rock or a single carbonate component (Urey 1947).

Carbonate clumped-isotope thermometry $\left(\Delta_{47}\right)$ can deconvolve the contribution of temperature from fluid chemistry on mineral $\delta^{18} \mathrm{O}$ (Eiler $2007,2011)$. Thus it is a powerful tool with the potential to unpack the complex history of depositional and burial events that transform carbonate sediments into rocks (Eiler 2007, 2011). Over the last few years, the $\Delta_{47}$ temperature dependence of ${ }^{13} \mathrm{C}-{ }^{18} \mathrm{O}$ "clumps" has been calibrated in many laboratories, and recent efforts from a few different labs demonstrate consistent temperature dependencies for calcite, dolomite, aragonite, siderite, and carbonate substituted into apatite for temperatures ranging from 0 to $350^{\circ} \mathrm{C}$ (Henkes et al. 2013; Wacker et al. 2013, 2014, 2016; Fernandez et al. 2014; Tang et al. 2014; Defliese et al. 2015; Kele et al. 2015; Bonifacie et al. 2017). Additional efforts to decrease the sample size requirements from $10 \mathrm{mg}$ to a few hundred $\mu \mathrm{g}$ per replicate make phasespecific work possible (e.g. Müller et al. 2017a). The measured abundance of ${ }^{13} \mathrm{C}-{ }^{18} \mathrm{O}$ "clumps" is accompanied by measurement of mineral $\delta^{18} \mathrm{O}$, which, in conjunction with $\Delta_{47}$ temperature, can then be used to calculate the precipitating-fluid $\delta^{18} \mathrm{O}$ at assumed equilibrium.

Our study of shallowly-buried carbonates over a long period of time is in part motivated by the observed large change in mineral $\delta^{18} \mathrm{O}$ over the last 600 million years (Shields and Veizer 2002; Knauth 2005; Jaffrés et al. 2007; Prokoph et al. 2008). This signal is seen in a range of minerals including carbonates and has been explained with two end-member interpretations: 1) an evolution of seawater $\delta^{18} \mathrm{O}$ values to $-6 \%$ in the Ediacaran (Shields and Veizer 2002; Kasting et al. 2006; Jaffrés et al. 2007; Prokoph et al. 2008) or 2) warmer surface temperatures as high as $40^{\circ} \mathrm{C}$ in the Neoproterozoic (Knauth 2005; Robert and Chaussidon 2006; Gaucher et al. 2008). To fully distinguish between these end members or to accept some other yet unappreciated solution, we must first tackle the more basic question of what can be learned from the $\Delta_{47}$ temperature and reconstructed fluid $\delta^{18} \mathrm{O}$ of lithified carbonate rocks. Unpacking the potential range in $\Delta_{47}$ temperatures in heterogeneous carbonate rocks that results from shallow burial, cementation, dolomitization, and other 


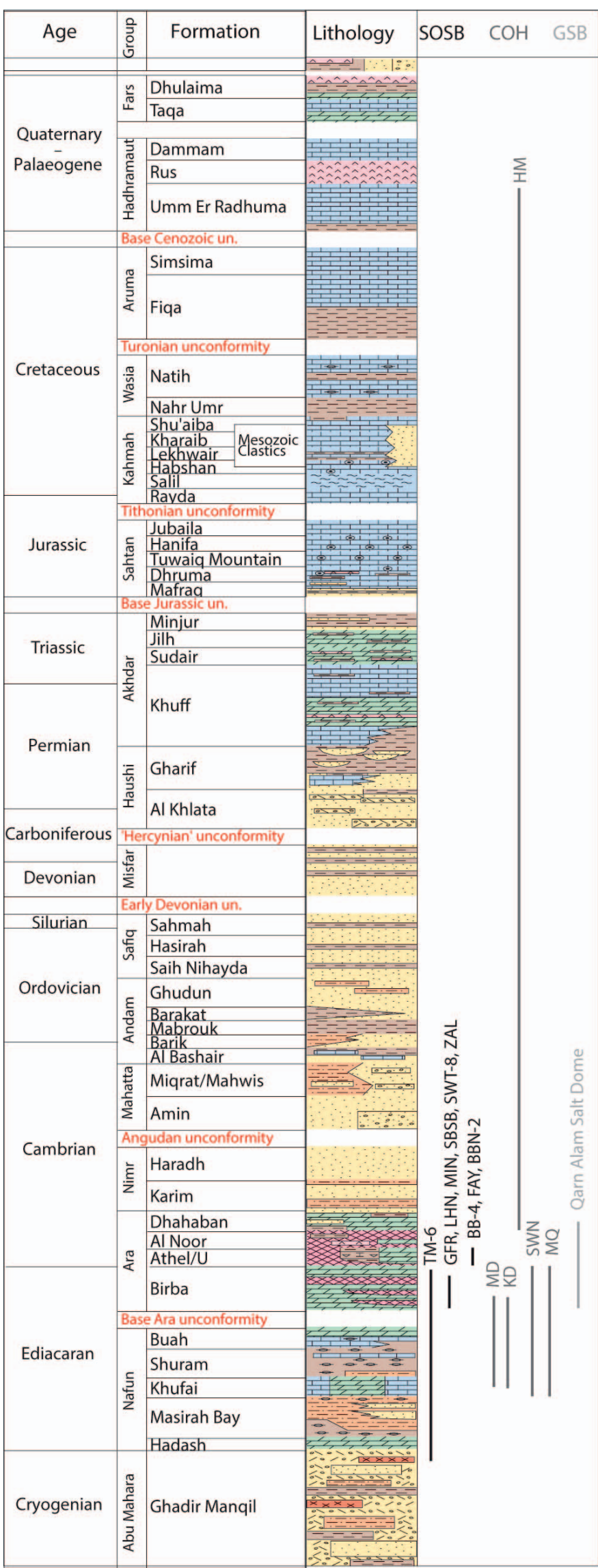

postdepositional processes remains a first-order question that requires large, well constrained datasets (Winkelstern and Lohmann 2016; Murray and Swart 2017). Carbonate rocks from the Sultanate of Oman provide a 600 -million-year record to test the utility of clumped-isotope thermometry in shallowly buried strata.

\section{GEOLOGIC BACKGROUND}

The stratigraphy of sedimentary rocks within the Sultanate of Oman affords an opportunity to explore shallow-burial processes and diagenetic environments (Figs. 1, 2). The oldest carbonates of Oman are some of the most shallowly buried Precambrian carbonates globally and include one of the oldest commercially viable oil-producing reservoirs (Figs. 1, 2; Schröder et al. 2005). Work on this petroleum reservoir and younger overlying reservoirs provides independent estimates of temperatures at maximum burial depths for the entire succession and access to subsurface samples (Fig. 2; Visser 1991; Al-Siyabi 2005; Schoenherr et al. 2007; Grosjean et al. 2009). These burial temperatures inform predictions of carbonate clumped-isotope thermometry for primary and diagenetic phases. In this study, we examine carbonate lithologies from the Ediacaran to Paleogene, buried between $350 \mathrm{~m}$ and $6000 \mathrm{~m}$, from both the subsurface and outcrops, that provide a test for the effects of carbonate diagenesis on the $\Delta_{47}$ temperature through time and across different burial environments.

\section{Depositional History of Oman Carbonates}

Permian-Paleogene Carbonates.-The carbonate-dominated Eocene and Paleocene Hadhramaut Group is regionally extensive and is found across the Arabian plate (Forbes et al. 2010). These carbonates are underlain by a regional hiatus that followed localized deposition of the Late Cretaceous Aruma Group carbonates and the closure of the Neo-Tethys Ocean (Figs. 1, 2). Before the closure of the Neo-Tethys Ocean, passivemargin carbonate-dominated sedimentation in a shallow epeiric sea across Oman formed the Permian-Cretaceous Akhdar, Sahtan, Kahmah, and Wasia groups (Fig. 3; Forbes et al. 2010; Koehrer et al. 2010; Bendias and Aigner 2015; Obermaier et al. 2015; Schlaich et al. 2017).

Ediacaran-Cambrian Ara Group.-The Permian Khuff Formation of the Akhdar Group was preceded by Paleozoic siliciclastic deposition until the carbonate and evaporite-dominated Ara Group that spans the Ediacaran-Cambrian boundary. The Ara Group records volcanism and basin compartmentalization associated with the convergence of East and West Gondwana (Allen 2007; Forbes et al. 2010) and is composed of six evaporite-carbonate cycles (A0/A1-A6; 1-2 Myr each; Mattes and Morris 1990; Schröder et al. 2004, 2005; Al-Siyabi 2005; Forbes et al. 2010; Grotzinger and Al-Rawahi 2014). Carbonates were deposited during transgressive to highstand conditions predominantly as boundstone and grainstone lithofacies (Fig. 4), while evaporites were deposited during relative lowstand conditions on the platforms and in surrounding basinal environments (Grotzinger and Al-Rawahi 2014). Today the Ara Group carbonates form "stringers" that float in the salt under lithostatic pressure. Additionally, carbonates found in a series of salt domes sourcing the Ghaba Salt Basin are correlated with the Ara Group (Al-Siyabi 2005; Reuning et al. 2009; Forbes et al. 2010; Mettraux et al. 2014, 2015).

FIG. 1.-Composite column of the stratigraphy of Oman. The stratigraphic range of each sampled subsurface well and outcrop section is shown on the right. Relevant locations for each well and outcrop area are shown in Figure 2A. Sample locations are grouped regionally from the South Oman Salt Basin (SOSB), the Central Oman High $(\mathrm{COH})$, and the Ghaba Salt Basin (GSB). The stratigraphic column is modified from Forbes et al. (2010). 

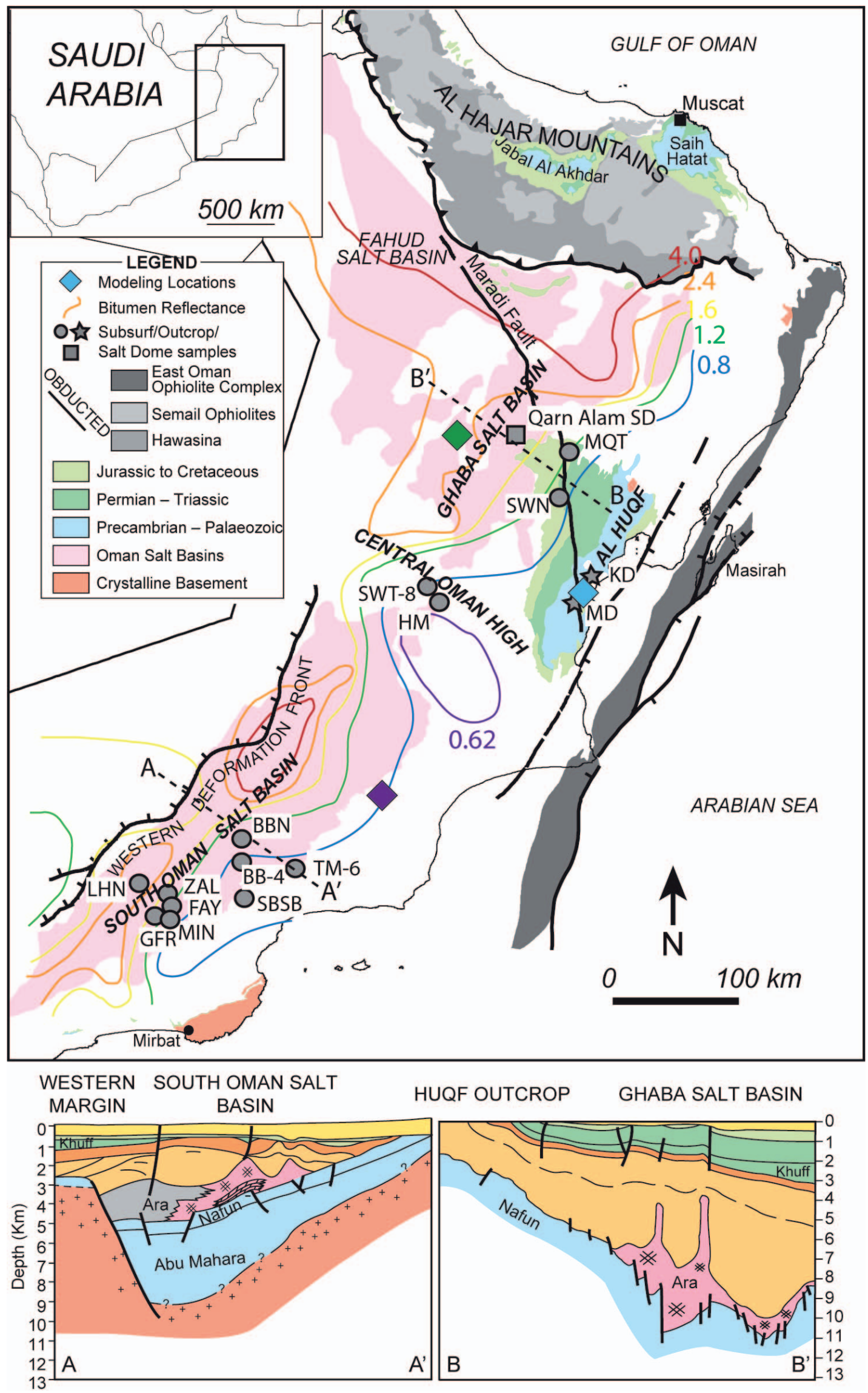
FIG. 2.-A) Simplified geologic map of Oman showing sample locations of subsurface wells (circles), outcrop sections (stars), and the Qarn Alam salt dome (squares). Approximate subsurface well locations are from Al-Siyabi (2005) and Forbes et al. (2010). Contours of bitumen reflectance data are plotted from Visser (1991). Timetemperature histories for three locations (diamonds) from Visser (1991) were used for modeling of solid state reordering (Fig. 11). The A-A' and B-B' lines are transects of the cross section shown below. B) Schematic geologic cross sections from A-A' and B-B' through the South Oman Salt Basin and Ghaba Salt Basin and Huqf outcrop area respectively. The South Oman Salt Basin is at a shallower depth than the Ghaba Salt Basin, and they are separated by the Central Oman High. Both the geologic map and the cross sections are modified from Forbes et al. (2010).

Ediacaran Nafun Group.-The Nafun Group is the oldest carbonatecontaining unit in Oman (Allen 2007). The unit consists of two large-scale siliciclastic-carbonate cycles of the Masirah Bay and Khufai formations and the Shuram and Buah formations (Fig. 1; Allen 2007; Bowring et al. 2007). The carbonates are composed of a wide range of lithofacies including mudstone, stromatolite boundstone, and grainstone (Fig. 5). Lithofacies associations generally define shallowing-upwards trends, and a range of depositional environments are preserved, including deeper marine environments below storm-weather wave base, shallow marine grainstone shoals, and peritidal and lagoonal environments (McCarron 1999; Cozzi et al. 2004; Le Guerroué et al. 2006; Osburn et al. 2014).

\section{Estimated Burial History}

Carbonates from three distinct regions sampled in this study have different burial histories: A) the South Oman Salt Basin (SOSB) and

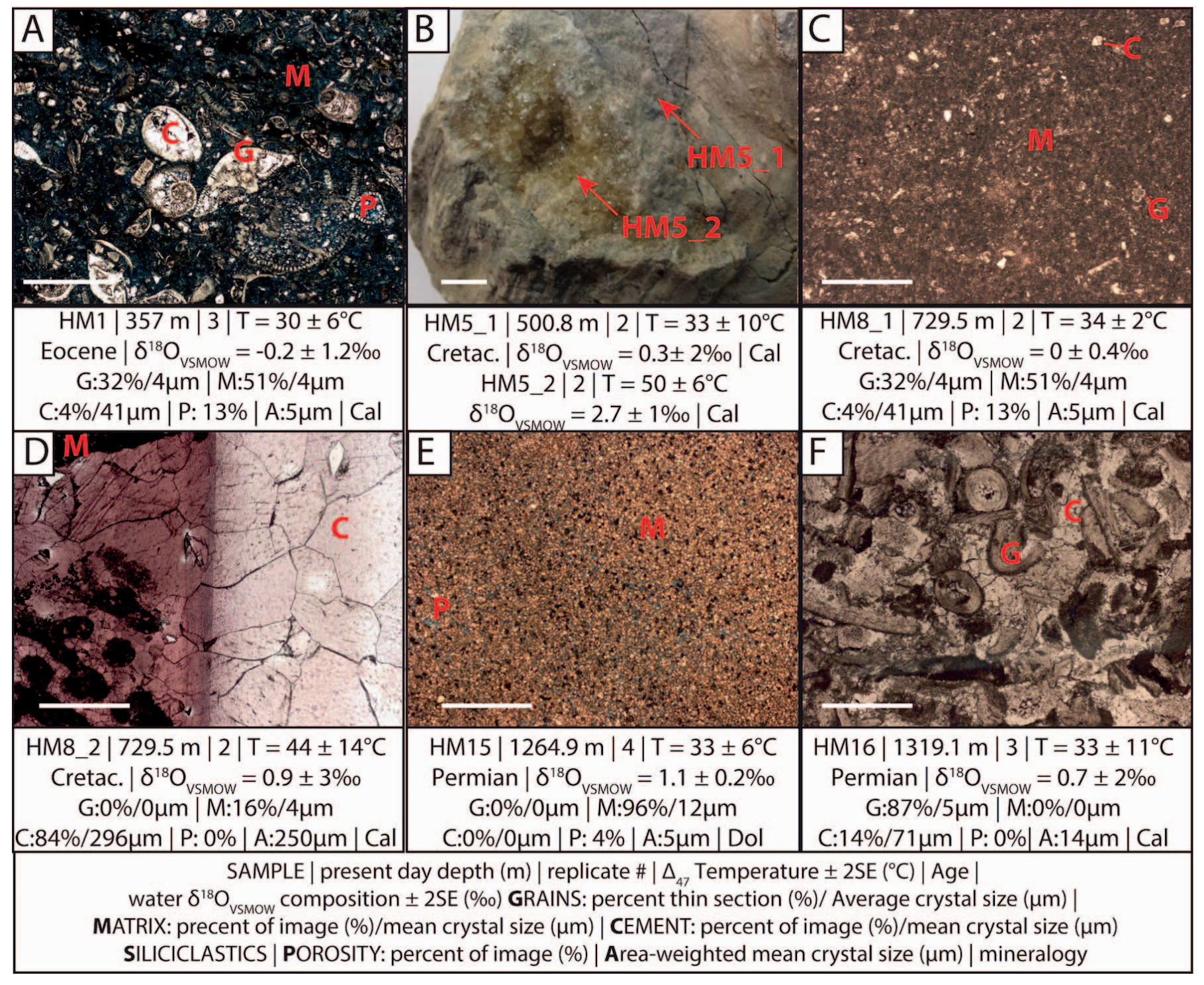

FIG. 3.-A-F) Petrographic images for Permian-Paleogene carbonates. The values given below the slides are sample name, present-day depth, number of sample replicates,

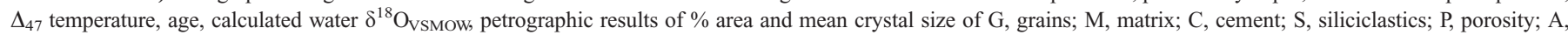
area-weighted mean crystal size in the image and mineralogy. Clumped-isotope and water $\delta^{18} \mathrm{O}_{\mathrm{VSMOw}}$ error is $2 \mathrm{SE}$. Co-occurring calcite spar cement has higher $\mathrm{T}\left(\Delta_{47}\right)$ than the surrounding matrix (see Part B). Epoxy is stained blue (see Part A) and thin sections are occasionally stained with alizarin-red staining solution for calcite (see Part D). Scale bars are $500 \mu \mathrm{m}$. 


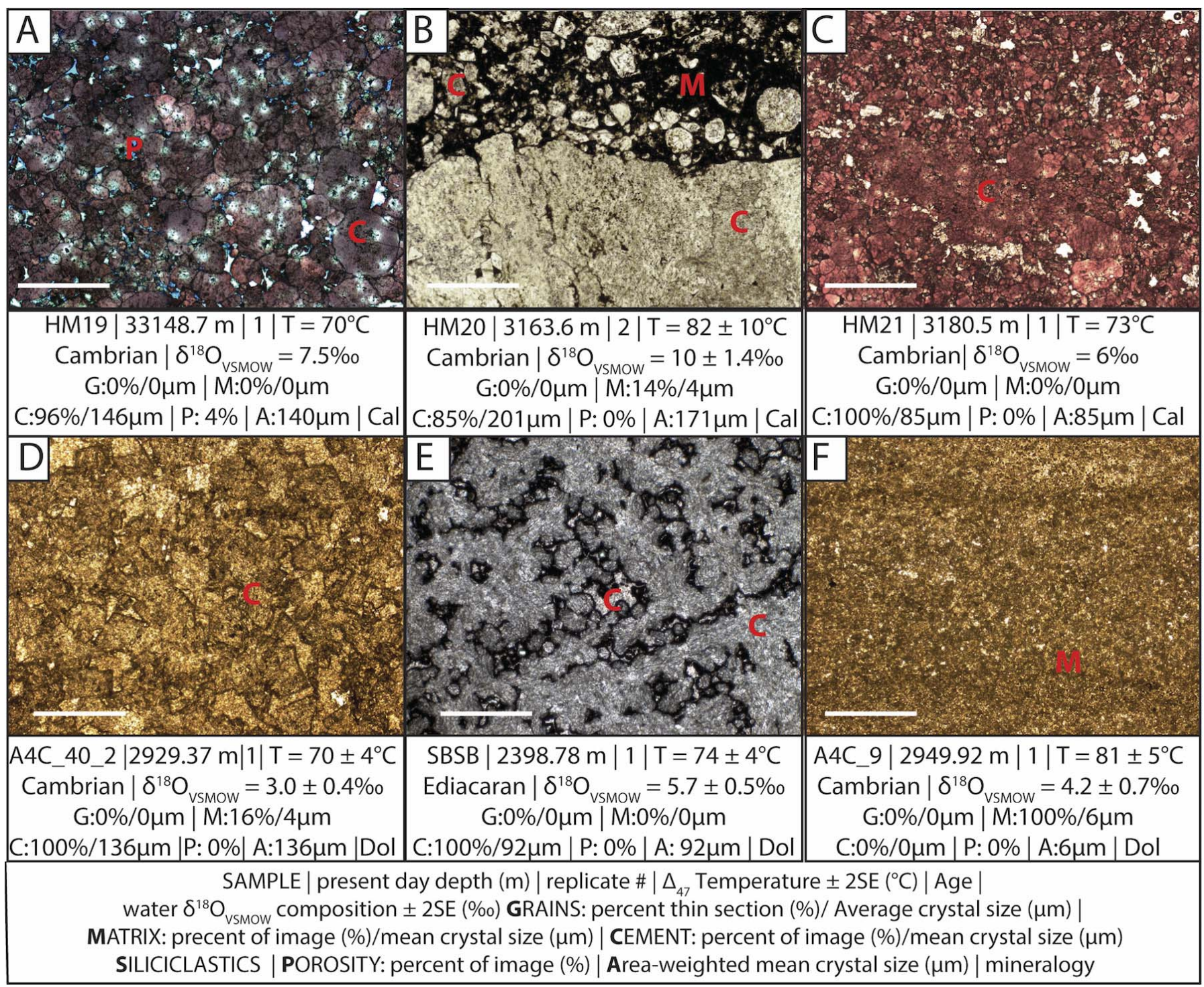

FIG. 4.-A-F) Petrographic images for Ediacaran-Cambrian Ara Group carbonates. The values given below the slides are sample name, present-day depth, number of sample replicates, $\Delta_{47}$ temperature, age, calculated water $\delta^{18} \mathrm{O}_{\mathrm{VSM}}$, petrographic results of $\%$ area and mean crystal size of G, grains; $\mathrm{M}$, matrix; C, cement; $\mathrm{S}$, siliciclastics; $\mathrm{P}$, porosity; A, area-weighted mean crystal size in the image and mineralogy. Clumped isotope and water $\delta^{18} \mathrm{O}_{\mathrm{VSMOw}}$ error is $2 \mathrm{SE}$. Epoxy is stained blue (see Part A) and thin sections are occasionally stained with alizarin-red staining solution for calcite (see Parts A and C). Scale bars are $500 \mu \mathrm{m}$.

Eastern Flank, B) the Central Oman High, and C) the Ghaba Salt Basin (Fig. 2). Across the SOSB and Central Oman High, current in-situ borehole temperature measurements do not exceed $100^{\circ} \mathrm{C}$ until $4000 \mathrm{~m}$ for a wide variety of wells (Schoenherr et al. 2007). The salt domes sourcing the Ghaba Salt Basin are sourcing carbonates that have been buried up to depths of $\sim 9 \mathrm{~km}$ and are the most deeply buried samples from this study (Fig. 2; Reuning et al. 2009).

The Central Oman High separates the SOSB from the deeper Ghaba Salt Basin to the north. Many of the samples of this study come from the Central Oman High, from either the Huqf outcrop area or wells HM and MQ (Figs. 1, 2). The Central Oman High is interpreted as an area dominated by long-term uplift since at least the Permian, with younger units thinning towards and onlapping the high (Gorin et al. 1982; Ries and Shackleton 1990). The oldest stratigraphy examined in this study experienced large-scale folding likely related to the establishment of the high (Gorin et al. 1982; Ries and Shackleton 1990). Younger stratigraphy including the siliciclastic Cambrian Mahatta Humaid Group and late Paleozoic Haushi Group display no structural folding and onlap the Ediacaran sedimentary rocks, suggesting that deformation and uplift occurred before, during, and after deposition of the Nafun and Ara groups (Gorin et al. 1982; Ries and Shackleton 1990).

Constraints on burial history include data from apatite thermochronology, which has $\sim 100^{\circ} \mathrm{C}$ temperature sensitivities on $100 \mathrm{Myr}$ timescales. Fission-track ages from Nafun Group detrital apatites, sourced from the 650-750 Ma granitic basement, range from 650 to 400 Ma with a peak at $450 \mathrm{Ma}$ in wells from the SOSB and Central Oman High (Visser 1991). This data suggest that some wells never reached the apatite closure temperature of $\sim 100^{\circ} \mathrm{C}$ during burial and other wells experienced significant uplift around $450 \mathrm{Ma}$ and saw maximum temperatures $<100^{\circ} \mathrm{C}$ for the rest of the Phanerozoic Eon. 


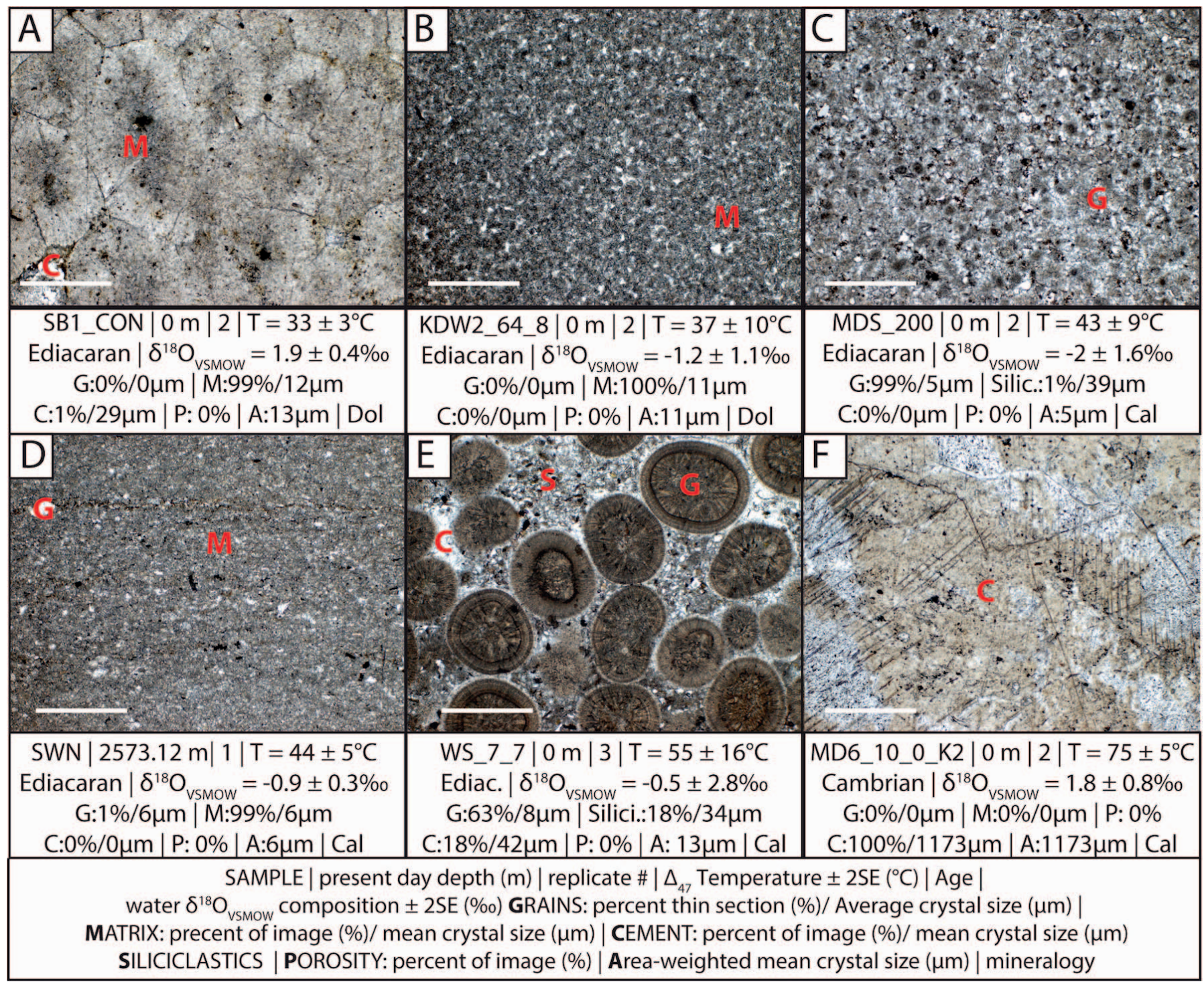

FIG. 5.-A-F) Petrographic images for Ediacaran Nafun Group carbonates. The values given below the slides are sample name, present-day depth, number of sample replicates, $\Delta_{47}$ temperature, age, calculated water $\delta^{18} \mathrm{O}_{\mathrm{VSMO}}$, petrographic results of \% area and mean crystal size of G, grains; M, matrix; C, cement; S, siliciclastics; $\mathrm{P}$, porosity; A, area-weighted mean crystal size in the image and mineralogy. Clumped isotope and water $\delta^{18} \mathrm{O}_{\mathrm{VSMOW}}$ error is $2 \mathrm{SE}$. Epoxy is not stained blue. Scale bars are 500 $\mu \mathrm{m}$.

Clay mineralogies in the Shuram and Buah formations in the Huqf outcrop area include illite, illite-smectite complexes, smectite, and kaolinite (Dubreuilh et al. 1992), which suggests that strata have not experienced the full smectite-to-illite transition (burial $<3000 \mathrm{~m}$ )

Thermal maturity of organic material further constrains the maximum temperature these rocks have experienced in their burial history. The organic material from the Ara Group in well TM6 in the South Oman Salt Basin is classified as immature and was not subjected to temperatures greater than $60^{\circ} \mathrm{C}$, based on hydrogen indices of 450-600 and Tmax of hydrocarbon release of $423-433^{\circ} \mathrm{C}$ from Rock Eval (Grosjean et al. 2009, 2012). Wells from the SOSB and Central Oman High have vitrinite reflectance equivalence (VRE) of 0.6 to $0.8 \%$ for the Nafun and Ara Group source rocks (oil generation occurs between 0.6 and 1.2\%; Fig. 2; Visser 1991). In a more recent study using a similar bitumen reflectance metric, samples from subsurface wells in the SOSB currently at $<4000 \mathrm{~m}$ depth have maximum paleo-burial temperatures $<100^{\circ} \mathrm{C}$ except for a few samples from Minassa (Schoenherr et al. 2007).

\section{METHODS}

\section{Sample Collection and Preparation}

To constrain the variability of temperature and fluid composition recorded by marine carbonate rocks, 180 samples from a range of burial environments (currently in both the subsurface and surface) and ages (50 to

$\sim 600 \mathrm{Ma}$ ) were analyzed from the South Oman Salt Basin and Eastern Flank, the Central Oman High, salt domes accessing the Ghaba Salt Basin, and the Oman Mountains (Figs. 1, 2; Schröder et al. 2004; Al-Siyabi 2005 Forbes et al. 2010). Carbonate samples from the subsurface were collected from cores or cuttings. Where possible, wells with in-situ measurements of borehole temperature were used to best constrain the current geotherm. 
TABLE 1.-Permian-Paleogene carbonates. Isotopic composition of analyzed samples (\%o).

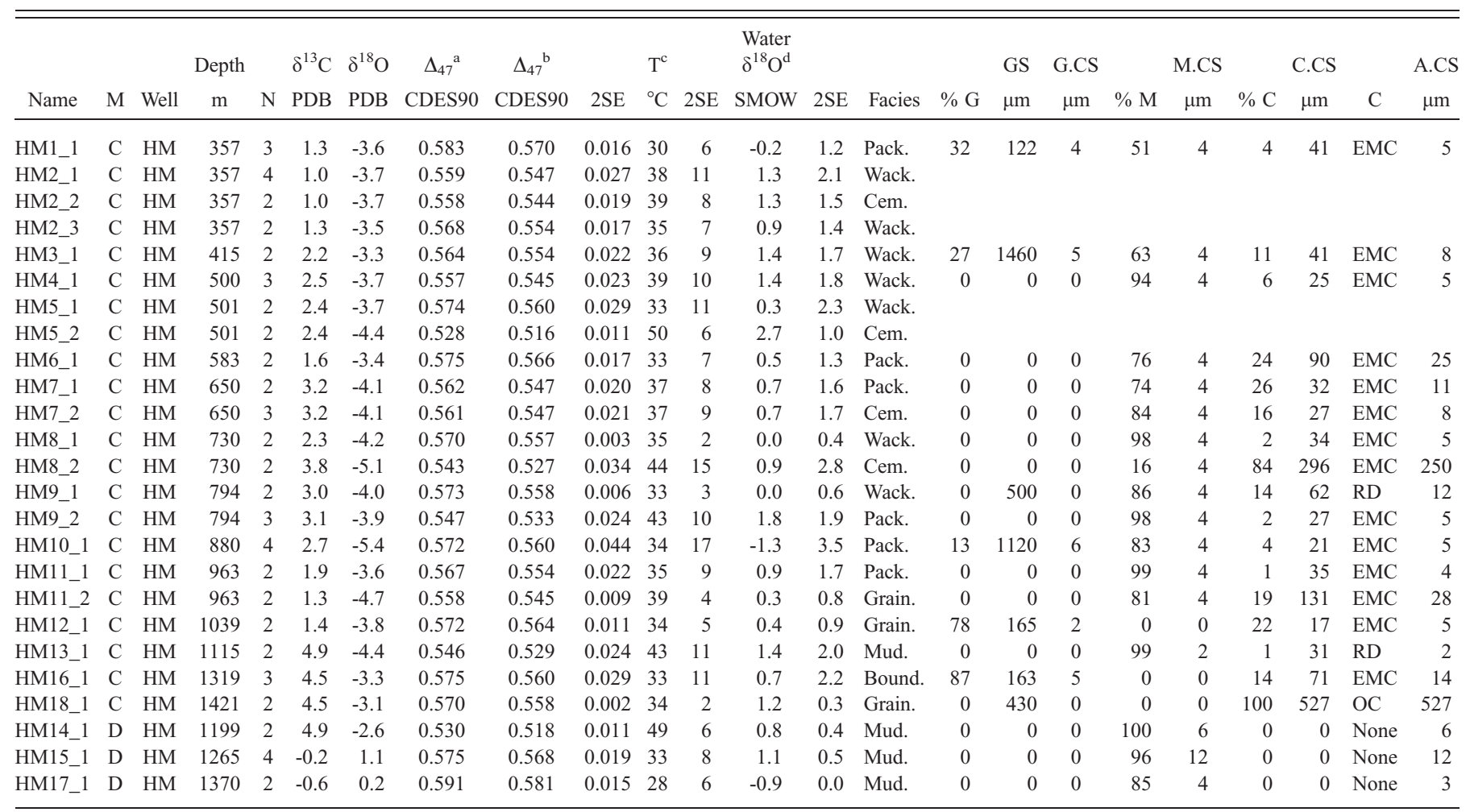

${ }^{\mathrm{a}}$ Calculated using ${ }^{17} \mathrm{O}$ parameters from Huntington et al. (2009), ${ }^{\mathrm{b}}$ Calculated using ${ }^{17} \mathrm{O}$ parameters from Brand et al. (2010).

${ }^{c} \Delta_{47 \operatorname{CDES} 90}=0.0428( \pm 0.0033) * 10^{6} / \mathrm{T}^{2}+0.1174( \pm 0.0248)$ (Bonifacie et al. 2017, Eq. 1)

${ }^{\mathrm{d}}$ Calculated using mineral-water fractionation equations from Kim and O’Neil (1997) and Horita et al. (2014).

Outcrop samples of Ara Group-equivalent rocks from the Qarn Alam salt dome were sampled as well (Reuning et al. 2009; Mettraux et al. 2014, 2015). Outcrop samples of the Nafun Group were collected from the Huqf outcrop area in Central Oman during three field seasons in 2009, 2010, and 2011. After sampling, outcrop hand samples were cut and polished to expose an unweathered face before further analysis.

\section{Petrographic Analysis}

Thin sections of 50 representative samples from the Permian-Paleogene samples $(\mathrm{n}=20)$, Ara Group $(\mathrm{n}=13)$ and Nafun Group $(\mathrm{n}=17)$ carbonates were quantitatively analyzed. Representative images at $5 \times$ resolution ( $\sim 2.5 \mathrm{~cm}$ across) were collected from the drill area (Figs. 3, 4, 5; see Supplemental Materials). Images were analyzed using Fiji, an opensource image-analysis software tool (Schindelin et al. 2012). The mean crystal size of three components as grains (G.CS), matrix (M.CS), and cement (C.CS) was calculated based on 10-40 individual measurements of crystal diameter. For example, if a grain was micritized, the average crystal size within the grain (G.CS) reflects the mean crystal size in the grain, while the mean grain size of the grain is the average of grain-diameter measurements (GS) (Tables 1, 2, 3). The \% area of open porosity, grains, matrix, and cement components was measured using a thresholding protocol we developed in Fiji that includes background subtraction, deconvolving colors, and thresholding. The mean crystal size for the entire thin section was calculated as a weighted mean of each component mean (A.CS). Facies were classified using the Dunham classification scheme, and specific grains (e.g., ooids, pisoids), matrix (e.g., micrite, microspar) and cement types (e.g., equant mosaic (EMC), overgrowth (OC)). See Supplemental Materials for raw data.

\section{Scanning Electron Microscopy (SEM)}

High-resolution scanning electron microscopy imaging of 14 thinsection samples was completed for additional context and crystal size verification, including six Permian-Paleogene carbonates, two Ara Group carbonates, and six Nafun Group samples. Images were collected with a ZEISS 1550 VP Field Emission Scanning Electron Microscope (SEM) equipped with an Oxford INCA Energy 300 X-Ray Energy Dispersive Spectrometer (EDS) system in the California Institute of Technology Geological and Planetary Sciences Division Analytical Facility. Images were collected at a working distance of 8-9 mm using a Quadrant backscattering detector (QBSD). In addition, EDS measurements and maps were made to identify in situ distributions of calcite, dolomite, clay, and quartz grains. All SEM data is presented in the Supplemental Materials.

\section{Bulk Powder X-Ray Diffraction (XRD)}

XRD measurements were made on each powder used for clumpedisotope measurements on a PANalytical X'Pert Pro in the Material Science Department at the California Institute of Technology. Scans were run from 5 to $70^{\circ} 2 \theta$ with a step size of 0.008 and a scan step time of $10.16 \mathrm{~s}$. A Cu anode was used at $45 \mathrm{kV}$ and $40 \mathrm{~mA}$. A zero-background silicon plate was used for all measurements because of sample size limitations. To determine relative abundances of calcite and dolomite in each sample, the relative peak height intensities of the major calcite and dolomite peaks at $29.5^{\circ} 2 \theta$ and $30.7^{\circ} 2 \theta$, respectively, were used (Supplemental Materials; Tennant 
TABLE 2.-Ara Group isotopic composition of analyzed samples (\%o).

\begin{tabular}{|c|c|c|c|c|c|c|c|c|c|c|c|c|c|c|c|c|c|c|c|c|c|c|c|}
\hline Name & $\mathrm{M}$ & Well & Depth & $\mathrm{N}$ & $\begin{array}{l}\delta^{13} \mathrm{C} \\
\mathrm{PDB}\end{array}$ & $\begin{array}{l}\delta^{18} \mathrm{O} \\
\mathrm{PDB}\end{array}$ & $\begin{array}{c}\Delta_{47^{\mathrm{a}}} \\
\operatorname{CDES} 90\end{array}$ & $\begin{array}{c}\Delta_{47^{\mathrm{b}}} \\
\mathrm{CDES} 90\end{array}$ & 2SE & $\begin{array}{l}\mathrm{T}^{\mathrm{c}} \\
{ }^{\circ} \mathrm{C}\end{array}$ & 2SE & $\begin{array}{c}\text { Water } \\
\delta^{18} \mathrm{O}^{\mathrm{d}} \\
\text { SMOW }\end{array}$ & 2SE & Facies & $\begin{array}{l}\% \\
\mathrm{G}\end{array}$ & $\begin{array}{l}\mathrm{GS} \\
\mu \mathrm{m}\end{array}$ & $\begin{array}{c}\text { G.CS } \\
\mu \mathrm{m}\end{array}$ & $\begin{array}{l}\% \\
M\end{array}$ & $\begin{array}{c}\text { M.CS } \\
\mu \mathrm{m}\end{array}$ & $\begin{array}{l}\% \\
\mathrm{C}\end{array}$ & $\begin{array}{l}\text { C.CS } \\
\mu \mathrm{m}\end{array}$ & $\mathrm{C}$ & $\begin{array}{c}\text { A.CS } \\
\mu \mathrm{m}\end{array}$ \\
\hline HM20_1 & $\mathrm{C}$ & HM & 3164 & 2 & 1.1 & -2.1 & 0.456 & 0.450 & 0.014 & 82 & 10 & 10.1 & 1.5 & Pack. & 0 & 0 & 0 & 15 & 4 & 85 & 201 & EMC & 171 \\
\hline HM21_1 & $\mathrm{C}$ & $\mathrm{HM}$ & 3181 & 1 & -0.6 & -4.5 & 0.474 & 0.464 & 0.004 & 73 & 4 & 6.3 & 0.6 & Pack. & 0 & 0 & 0 & 0 & 0 & 100 & 85 & EMC & 85 \\
\hline SB1_PIS & $\mathrm{D}$ & $\mathrm{KD}$ & 0 & 1 & 4.2 & -0.5 & 0.543 & 0.527 & 0.004 & 44 & 3 & 1.9 & 0.2 & Grain. & 80 & 897 & 4 & 0 & 0 & 4 & 64 & EMC & 6 \\
\hline SBSB_2461_75 & $\mathrm{D}$ & SBSB & 2462 & 1 & 1.9 & -2.8 & 0.493 & 0.481 & 0.004 & 64 & 3 & 3.3 & 0.3 & Bound. & 0 & 0 & 0 & 0 & 0 & 100 & 132 & $\mathrm{OC}$ & 132 \\
\hline SBSB_2765_73 & $\mathrm{D}$ & SBSB & 2766 & 1 & 3.1 & -1.5 & 0.546 & 0.533 & 0.004 & 43 & 3 & 0.7 & 0.3 & Mud. & 0 & 0 & 0 & 100 & 12 & 0 & 0 & None & 12 \\
\hline A4C_40_2 & $\mathrm{D}$ & BB4 & 2929 & 1 & -1.9 & -3.9 & 0.480 & 0.472 & 0.004 & 70 & 4 & 3.0 & 0.4 & Cutt. & 0 & 0 & 0 & 0 & 0 & 100 & 136 & $\mathrm{OC}$ & 136 \\
\hline A4C_40_3 & $\mathrm{D}$ & BB4 & 2929 & 2 & -1.9 & -3.9 & 0.484 & 0.477 & 0.020 & 69 & 12 & 2.8 & 1.6 & Cutt. & & & & & & & & & \\
\hline A4C_24 & $\mathrm{D}$ & BB4 & 2940 & 2 & -3.1 & -5.5 & 0.503 & 0.497 & 0.021 & 60 & 11 & -0.2 & 1.5 & Cutt. & & & & & & & & & \\
\hline A4C_24_2 & $\mathrm{D}$ & BB4 & 2940 & 3 & -3.1 & -5.4 & 0.513 & 0.507 & 0.004 & 56 & 3 & -0.8 & 0.1 & Cutt. & & & & & & & & & \\
\hline MQ1_2994 & $\mathrm{D}$ & MQ & 2994 & 1 & 2.5 & -3.2 & 0.479 & 0.466 & 0.004 & 71 & 4 & 3.9 & 0.5 & Cutt. & & & & & & & & & \\
\hline MQ1_3026 & D & MQ & 3026 & 1 & 1.7 & -4.0 & 0.499 & 0.482 & 0.004 & 62 & 3 & 1.6 & 0.2 & Cutt. & & & & & & & & & \\
\hline MQ1_3160 & $\mathrm{D}$ & MQ & 3160 & 2 & -0.3 & -3.6 & 0.463 & 0.454 & 0.002 & 79 & 3 & 4.7 & 0.5 & Cutt. & & & & & & & & & \\
\hline 1H1_A1C_031 & $\mathrm{D}$ & MIN & 3400 & 2 & 2.8 & -3.1 & 0.510 & 0.495 & 0.034 & 57 & 17 & 1.7 & 2.5 & Cutt. & & & & & & & & & \\
\hline 1H1_A3C & $\mathrm{D}$ & FAY & 4220 & 2 & -22.1 & -5.2 & 0.456 & 0.476 & 0.005 & 83 & 5 & 3. & 0.8 & Cutt. & & & & & & & & & \\
\hline 1H1_A3C_011 & $\mathrm{D}$ & FAY & 222 & 3 & -22.5 & -5.7 & 0.447 & 0.468 & 0.023 & 87 & 16 & 3 & 2.3 & Cutt. & & & & & & & & & \\
\hline GFR_102 & $\mathrm{D}$ & GFR & 4571 & 2 & 2.3 & -4.0 & 0.437 & 0.422 & 0.035 & 93 & 25 & 6. & 3.5 & $\mathrm{Cu}$ & & & & & & & & & \\
\hline ZAL_1_33 & $\mathrm{D}$ & ZAL & 948 & 2 & -0.7 & -4.8 & 0.454 & 0.443 & 0.017 & 84 & 12 & 4. & 1.7 & Cutt. & & & & & & & & & \\
\hline BBN_2_52 & $\mathrm{D}$ & BBN2 & 3884 & 2 & -2.5 & -4.9 & 0.439 & .432 & 0.004 & 92 & 5 & 5. & 0.9 & Cutt. & & & & & & & & & \\
\hline LHN_5842_8 & $\mathrm{D}$ & LHN & 5843 & 3 & 1.7 & -2.8 & 0.464 & 452 & 0.030 & 78 & 19 & 5. & 2.6 & Cutt. & & & & & & & & & \\
\hline LHN1 & $\mathrm{D}$ & LHN & 5848 & 3 & 1.6 & -2.9 & 0.432 & 417 & 0.042 & 96 & 32 & & 4.3 & Cutt. & & & & & & & & & \\
\hline LHN11 & $\mathrm{D}$ & LHN & 848 & 2 & 1.8 & -2.1 & 0.442 & 428 & 0.023 & 90 & 17 & 7. & 2.3 & Cutt. & & & & & & & & & \\
\hline LHN4 & $\mathrm{D}$ & LHN & 5848 & 2 & 2.0 & -1.4 & 0.489 & 0.475 & 0.028 & 66 & 16 & 5.0 & 2.2 & Cutt. & & & & & & & & & \\
\hline SWT8_3725.75 & $\mathrm{D}$ & SWT8 & 3726 & 2 & 0.3 & -2.7 & 0.505 & 0.491 & 0.035 & 59 & 18 & 2.5 & 2.6 & Rud. & 0 & 0 & 0 & 100 & 10 & 0 & 0 & None & 10 \\
\hline
\end{tabular}

${ }^{a}$ Calculated using ${ }^{17} \mathrm{O}$ parameters from Huntington et al. (2009).

${ }^{\mathrm{b}}$ Calculated using ${ }^{17} \mathrm{O}$ parameters from Brand et al. (2010).

${ }^{\mathrm{c}} \Delta_{47 \mathrm{CDES} 90}=0.0428( \pm 0.0033) * 10^{6} / \mathrm{T}^{2}+0.1174( \pm 0.0248)($ Bonifacie et al. 2017 , Eq. 1$)$

${ }^{d}$ Calculated using mineral-water fractionation equations from Kim and O'Neil (1997) and Horita et al. (2014).

and Berger 1956). Mixtures of known compositions of $100 \%, 80 \%, 60 \%$, $40 \%, 20 \%$, and $0 \%$ calcite with dolomite were used to create the following relationship of peak height to $\%$ dolomite:

$\%$ Dolomite $=0.0099$

$$
*\left(\frac{\text { Rel.Intensity of } \mathrm{CaMgCO}_{3}}{\text { Rel.Intensity of } \mathrm{CaMgCO}_{3}+\mathrm{CaCO}_{3}}-0.0526\right)
$$

$90 \%$ of the samples analyzed were pure endmembers of either calcite or dolomite. For the $10 \%$ of samples that include both calcite and dolomite, the acid digestion fractionation for calculating mineral $\delta^{18} \mathrm{O}_{\mathrm{VPDB}}$ and the mineral-water fractionation factor were made assuming a pure composition of the dominant mineralogy.

\section{Carbonate Clumped-Isotope Thermometry}

Samples of 9-12 mg of powder were weighed into silver capsules before being reacted in a phosphoric common acid bath $(\sim 103 \% ; 1.90<\rho<$ 1.92 ) for 20 minutes at $90^{\circ} \mathrm{C}$. Evolved $\mathrm{CO}_{2}$ was collected and purified with an automated acid digestion and gas purification device as described by Passey et al. (2010). This device includes passing the $\mathrm{CO}_{2}$ through multiple cryogenic traps using either a dry ice and ethanol mix or liquid nitrogen as well as through a Porapak-Q 120/80 mesh gas chromatography column held at $-20^{\circ} \mathrm{C}$ using a helium carrier gas. Sulfur was scrubbed from the
$\mathrm{CO}_{2}$ using an in-line silver wool trap. The $\mathrm{CO}_{2}$ was measured on one of two ThermoFinnigan MAT 253 IRMS housed at Caltech. Each measurement consisted of eight acquisitions $(16 \mathrm{~V}$ on $\mathrm{m} / \mathrm{z}=44)$ of seven cycles of unknown sample $\mathrm{CO}_{2}$ versus Oztech working gas as outlined by Huntington et al. (2009).

Data collection spanned March 2009 to July 2013, and over this interval and beyond, best practices in the clumped-isotope community have evolved to better address pressure baseline issues, nonlinearity in the source, scale compression, and necessary sample replication (e.g., Dennis et al. 2011; Bernasconi et al. 2013; Schauer et al. 2016; Daëron et al. 2016; Bonifacie et al. 2017). To best address the complexities of data processing over many months, two mass spectrometers, and samples of multiple mineralogies, gathered with and without $25^{\circ} \mathrm{C}$ equilibrated gases, we input over 1200 raw measurement files of $1000^{\circ} \mathrm{C}$ heated and $25^{\circ} \mathrm{C}$ equilibrated gases and carbonate standard data along with 270 raw measurement files of sample unknowns into Easotope, an open-source software tool specifically developed for clumped isotope data processing (John and Bowen 2016).

The carbonate $\delta^{18} \mathrm{O}$ values were calculated using a $90^{\circ} \mathrm{C}$ acid-digestion fractionation factor for calcite from Swart et al. (1991) and for dolomite from Rosenbaum and Sheppard (1986). Carbonate $\delta^{13} \mathrm{C}$ and $\delta^{18} \mathrm{O}$ values were drift-corrected using a 10 standard moving window to NBS-19 and NBS-19 calibrated internal Carrara Marble standards (HCM and CIT). We corrected all of the $\Delta_{47}$ data using a 10 standard moving window using 
TABLE 3.-Nafun Group isotopic composition of analyzed samples (\%o)

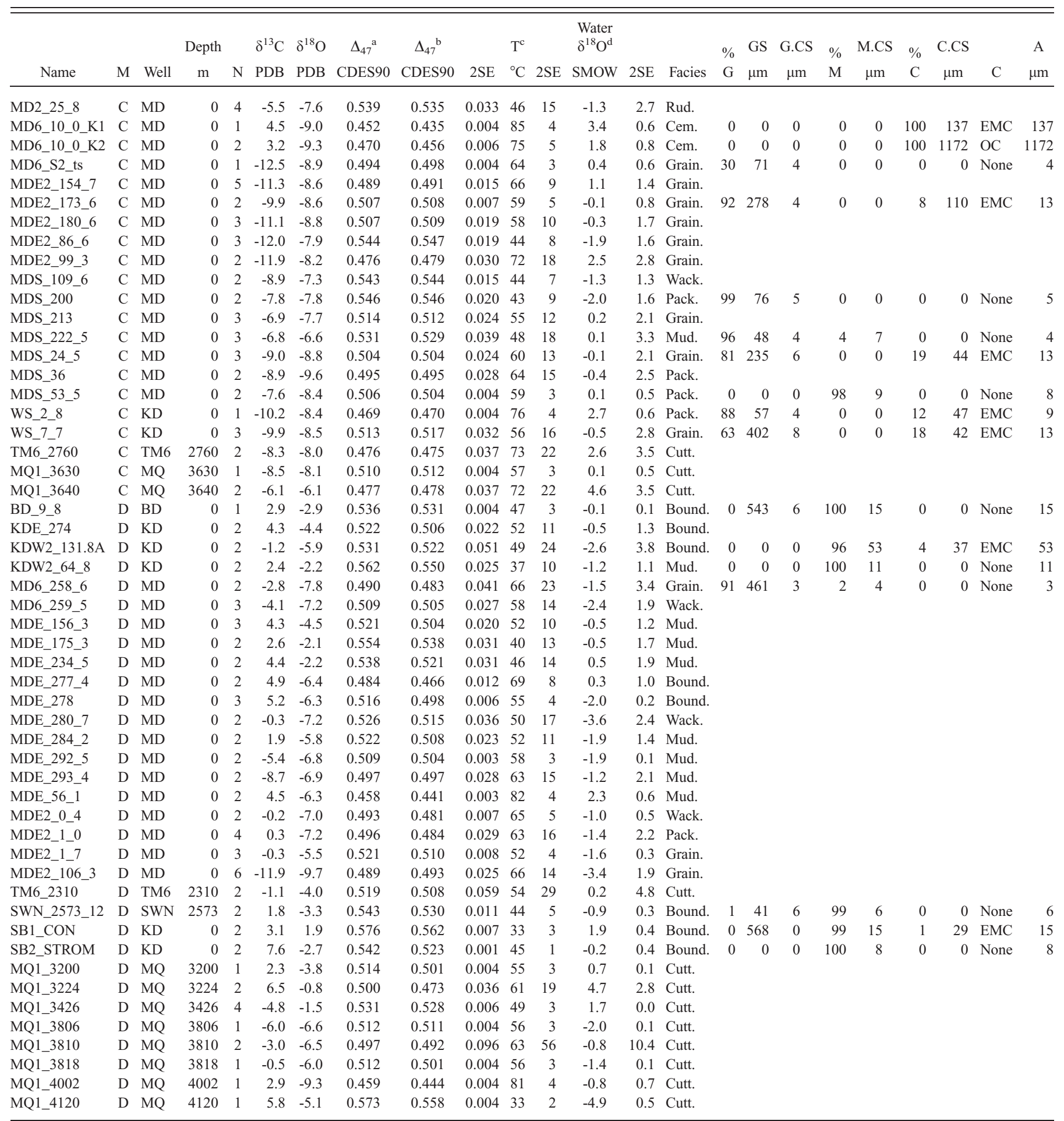

${ }^{\text {a }}$ Calculated using ${ }^{17} \mathrm{O}$ parameters from Huntington et al., 2009, ${ }^{\mathrm{b}}$ Calculated using ${ }^{17} \mathrm{O}$ parameters from Brand et al., 2010

${ }^{\mathrm{c}} \Delta_{47 \mathrm{CDES} 90}=0.0428( \pm 0.0033) * 10^{6} / \mathrm{T}^{2}+0.1174( \pm 0.0248)$ (Bonifacie et al., 2017, Eq. 1)

${ }^{\mathrm{d}}$ Calculated using mineral-water fractionation equations from Kim and O'Neil, 1997 and Horita et al., 2014 
TABLE 4.-Isotopic composition of analyzed CIT standards (\%o).

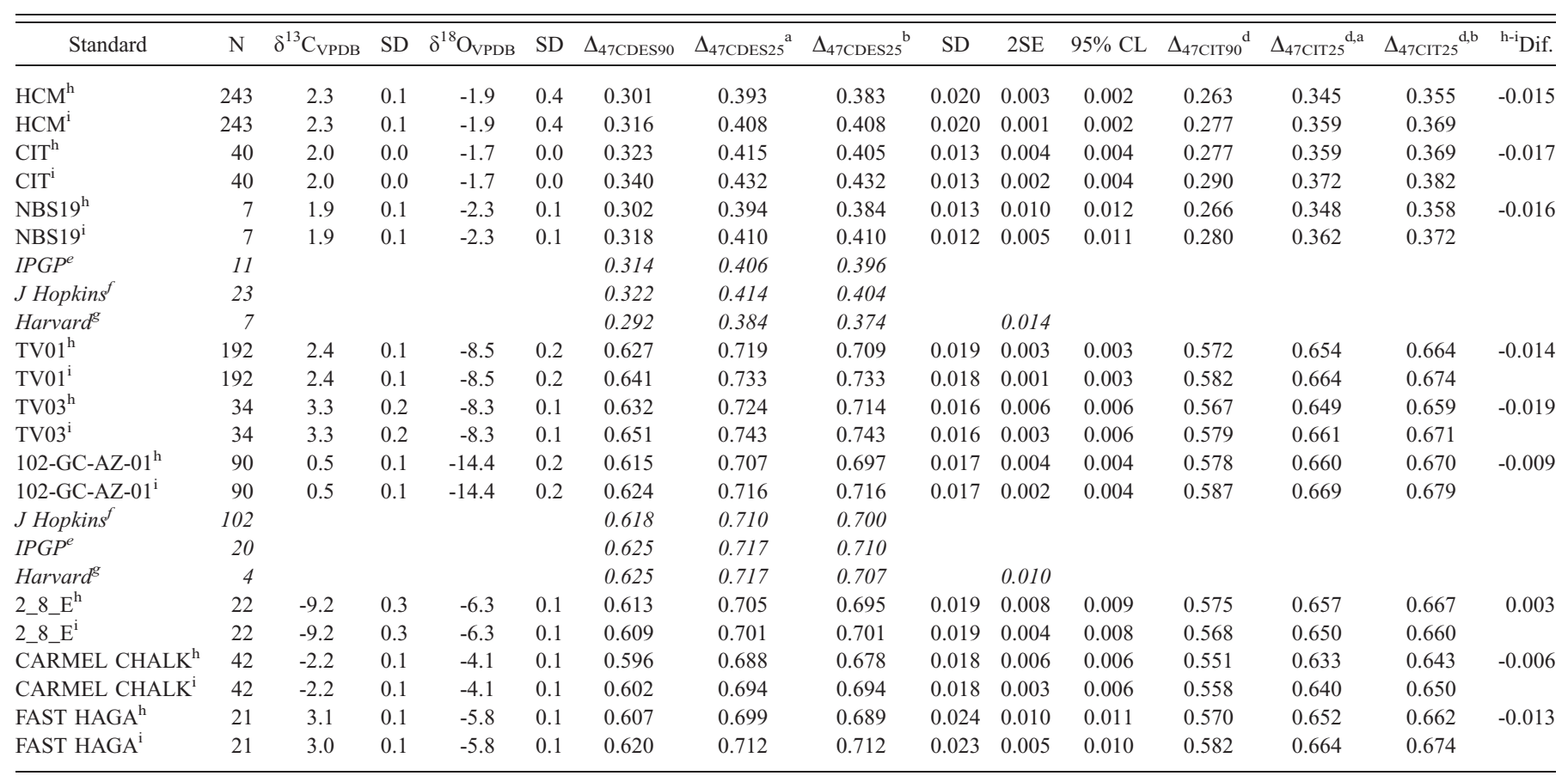

${ }^{a} 0.092$ Acid Fract. Factor following Henkes et al. (2013). ${ }^{\mathrm{b}}$ Calculated using a 0.082 Acid Fract. Factor following Defliese et al. (2015).

${ }^{\mathrm{d}} \Delta_{47 \text { CIT }}$ uses a 10 standard moving window, the HG intercept and slope and stretching factor outlined in Huntington et al. (2009).

Comparison data in italics from ${ }^{\mathrm{e}}$ Bonifaci et al. (2017), ${ }^{\mathrm{f}}$ Henkes et al. (2013), and ${ }^{\mathrm{g}}$ Dennis et al. (2011).

${ }^{\mathrm{h}}$ Data corrected using ${ }^{17} \mathrm{O}$ parameters from Brand et al. (2010), i Data corrected using ${ }^{17} \mathrm{O}$ parameters from Huntington et al. (2009).

heated gases, equilibrated gases (when available), and carbonate standards for both the linearity correction and empirical transfer function into the "absolute reference frame" or "carbon dioxide equilibrated scale" (CDES) as defined by Dennis et al. (2011) following the procedure outlined in the Supplemental Materials.

Following recent clumped-isotope studies, we recognize that the uncertainty on few replicate analyses has been underrepresented so to better represent the true uncertainty the error on each sample is presented as 2SE, twice the commonly reported 1SE (see Bonifacie et al. 2017; Müller et al. 2017a, 2017b).

Fluid compositions were calculated using the measured clumped-isotope temperatures and an equilibrium fractionation equation for calcite-water (Kim and O’Neil 1997). To calculate fluid compositions for dolomite samples, we compared published equilibrium fractionation equations for dolomite-water (and proto-dolomite-water) and found little difference ( \pm 1\%; Supplemental Materials; Matthews and Katz 1977; Vasconcelos et al. 2005; Horita 2014). We present water $\delta^{18} \mathrm{O}_{\mathrm{vSMOW}}$ values for dolomite in the main text using the equation from Horita (2014).

\section{RESULTS}

In Tables 1, 2, 3, and 4 and in the Supplemental Materials we present data and standards calculated using two sets of ${ }^{17} \mathrm{O}$ correction parameters (Huntington et al. 2009; Brand et al. 2010; Schauer et al. 2016; Daëron et al. 2016), two different acid-digestion fractionation factors (Henkes et al. 2013; Defliese et al. 2015; Bonifacie et al. 2017) and four recent calibration equations (Kele et al. 2015; Bonifacie et al. 2017; Kelson et al. 2017). We found our standard values $(n=691)$ were consistently more positive (avg. 0.012\%o) using the correction parameters from Huntington et al. (2009) compared to those from Brand et al. (2010) (Table 4). To maintain consistency with the temperature calibration equation $\Delta_{47 \mathrm{CDES} 90}$
$=0.0428( \pm 0.0033) * 10^{6} / \mathrm{T}^{2}+0.1174( \pm 0.0248)$ (Bonifacie et al. 2017, their Eq. 1) that includes data garnered at Caltech during the same time interval as our analyses, in the main text, our data were corrected in exactly the same way as the calibration data in Bonifacie et al. (2017) using parameters from Huntington et al. (2009). The results of this $\Delta_{47}$ calibration equation are within $1-3^{\circ} \mathrm{C}$ of Eq. 3 from Bonifacie et al. (2017), a composite of both synthetic and biogenic calcite, aragonite, and dolomite minerals analyzed at $70-90^{\circ} \mathrm{C}$ in eight different laboratories (Henkes et al. 2013; Fernandez et al. 2014; Tang et al. 2014; Wacker et al. 2014; Defliese et al. 2015; Kele et al. 2015; Bonifacie et al. 2017).

Summary data for 109 samples including 50 with petrographic analysis is presented in the main text (Tables 1,2, and 3). The comparative results of the correction parameters, calibration equations, acid fractionation factors, mineral-water equations, and the remaining 71 single-analysis samples can be found in the Supplemental Materials. Samples analyzed from Oman cluster into three populations based on their shared petrographic and clumped-isotope characteristics: Permian-Paleogene carbonates, Ediacaran-Cambrian Ara Group carbonates, and Ediacaran Nafun Group carbonates. Clumped-isotope temperature results and reconstructed water $\delta^{18} \mathrm{O}$ values are presented for individual samples $( \pm$ 2SE) and for the mean, median, minimum, and maximum measurement of each group by mineralogy ( $\pm 1 \mathrm{SD}, \mathrm{n}=\#$ of samples) (Table 5 ).

\section{Permian-Paleogene Carbonates}

All Permian-Paleogene samples come from a single well HM located on the Central Oman High. The samples currently sit $357 \mathrm{~m}$ to $1370 \mathrm{~m}$ below land surface. Present day borehole temperature measurements and stratigraphy are plotted in Figure 6. Sixteen of the samples are dominated by micrite $(>50 \%)$ and are either mudstone, wackestone or packstone lithofacies (Table 2; images of all samples are presented in the 
TABLE 5.-Group statistics.

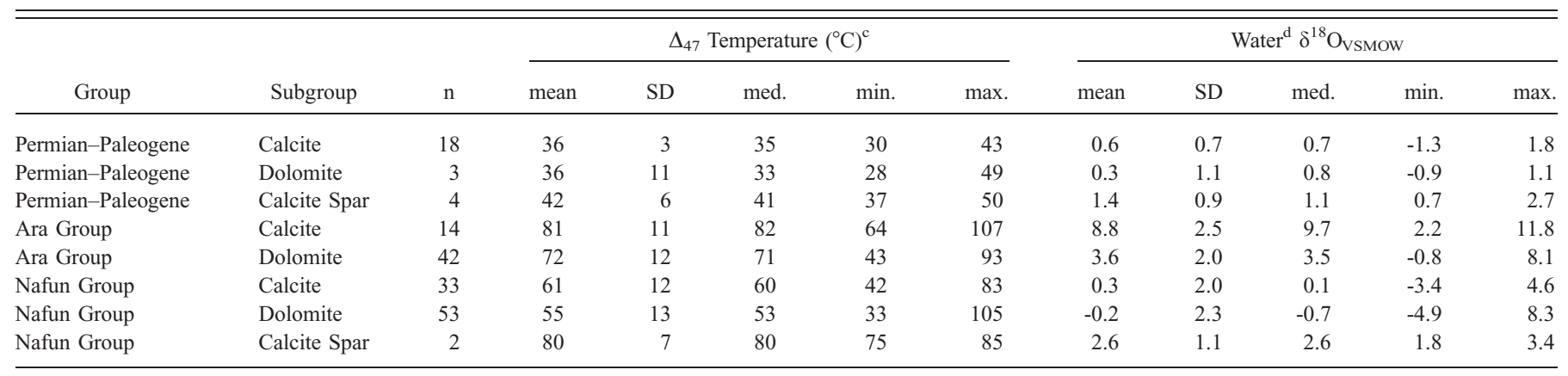

${ }^{\mathrm{c}} \Delta_{47 \mathrm{CDES} 90}=0.0428( \pm 0.0033) * 10^{6} / \mathrm{T}^{2}+0.1174( \pm 0.0248)$ (Bonifacie et al. 2017, Eq. 1$)$.

d mineral-water fractionation equations from Kim and O’Neil (1997) and Horita et al. (2014).

Supplemental Materials). All but 4 of the 25 samples have area-weighted average crystal sizes of $15 \mu \mathrm{m}$ or less (Fig. 7; Table 2). When there are fossils, they are usually benthic foraminifera in-filled with equant mosaic calcite cement (EMC). The fabric preservation of the fossil material varies and is either micritized or dissolved and reprecipitated as equant mosaic calcite cement. A few samples have disseminated small rhombohedral dolomite floating in the micrite matrix (HM1, HM9, HM13; Fig. 1A, Fig. SM1, see Supplemental Material). Only one grainstone sample from the
Permian Lower Khuff Formation is characterized by large overgrowth cement (avg. crystal size $=527 \mu \mathrm{m}$ ). In this sample, the fossils are rimmed with thin fibrous marine cements overgrown by post-compaction, coarse poikilotopic spar cement (HM18). Two other grainstone samples (HM12, HM16) have porosity-occluding, equant mosaic calcite cement crystals with average crystal sizes of 17 and $71 \mu \mathrm{m}$ respectively (Fig. 3F). Samples with residual intergranular primary porosity are limited to the most shallowly buried samples (HM1, HM3; Fig. 3A). Residual porosity along
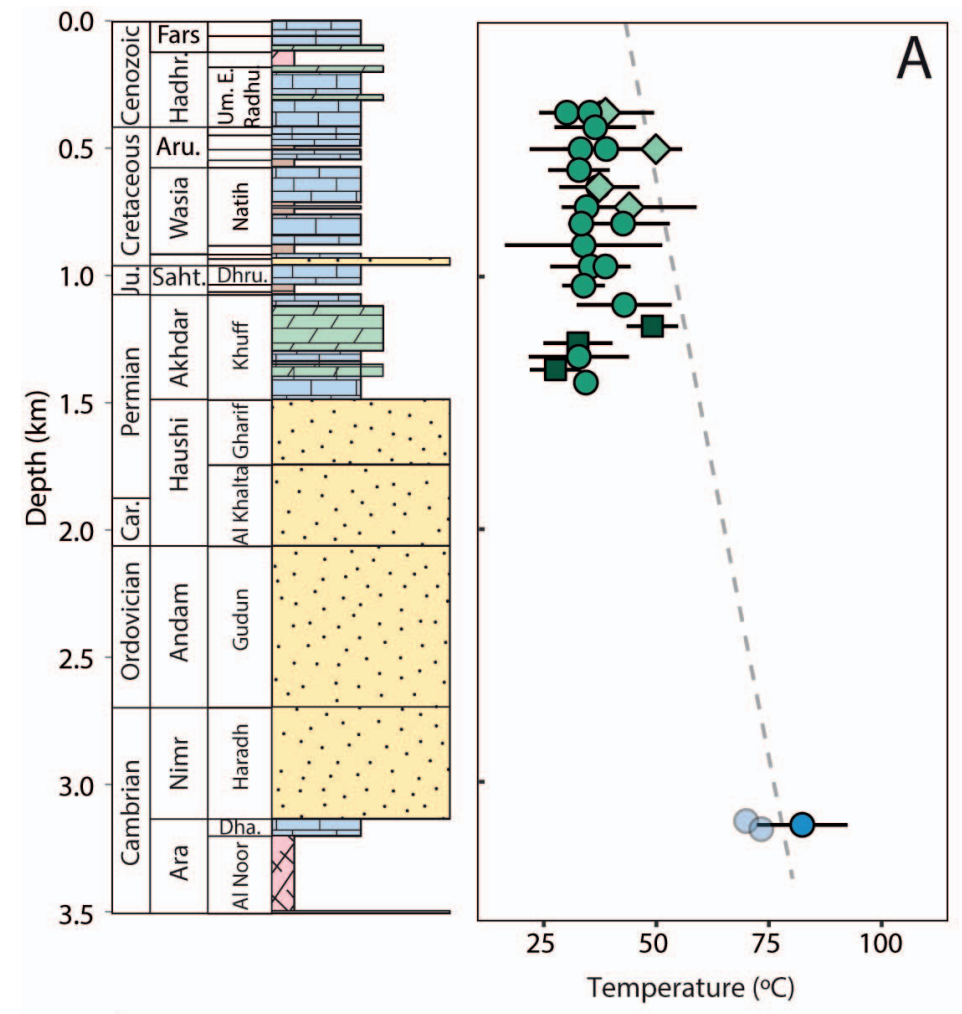
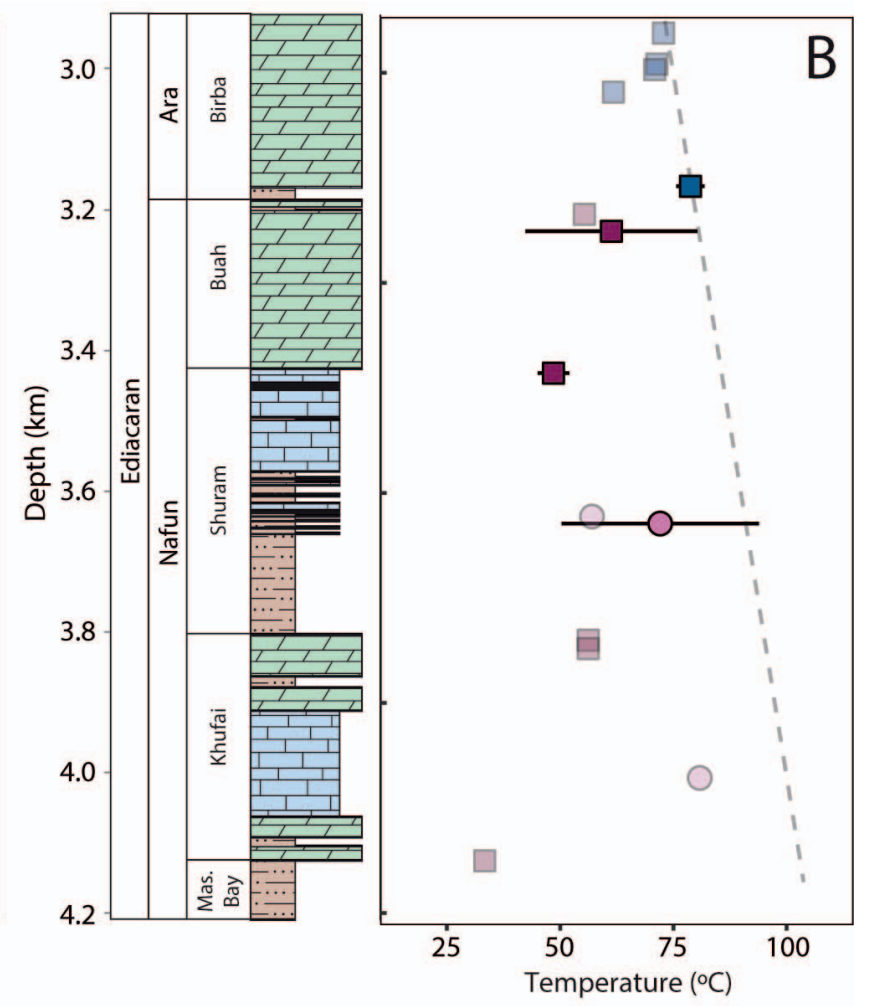

\begin{tabular}{|c|c|c|c|}
\hline $\begin{array}{l}\text { dimestone } \\
\text { dolomite }\end{array}$ & $\begin{array}{l}\square .9 \text { sandstone } \\
\ldots \ldots \text { siltstone }\end{array}$ & $\begin{array}{l}\text { XA evaporite } \\
=\text { geothermal gradient }\end{array}$ & $\begin{array}{l}\bigcirc \text { Eocene-Permian calcite } \bigcirc \text { Ara calcite } \bigcirc \text { Nafun Group calcite } \\
\square \text { Permian dolomite } \square \text { Ara dolomite } \square \text { Nafun Group dolomite } \\
\diamond \text { Void and fracture calcite }\end{array}$ \\
\hline
\end{tabular}

FIG. 6.-Generalized stratigraphic columns and $\Delta_{47}$ temperature versus current burial depth with the in-situ measured borehole temperature profile (dashed line) for two subsurface wells, HM and MQ, from the Central Oman High. $\Delta_{47}$ temperature results are from replicated samples (dark with \pm 2 SE error bars) and single analyses

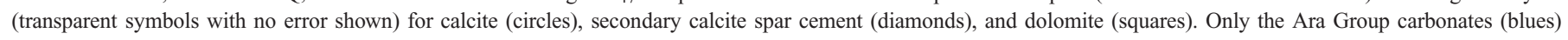
match current borehole temperatures in both wells. 

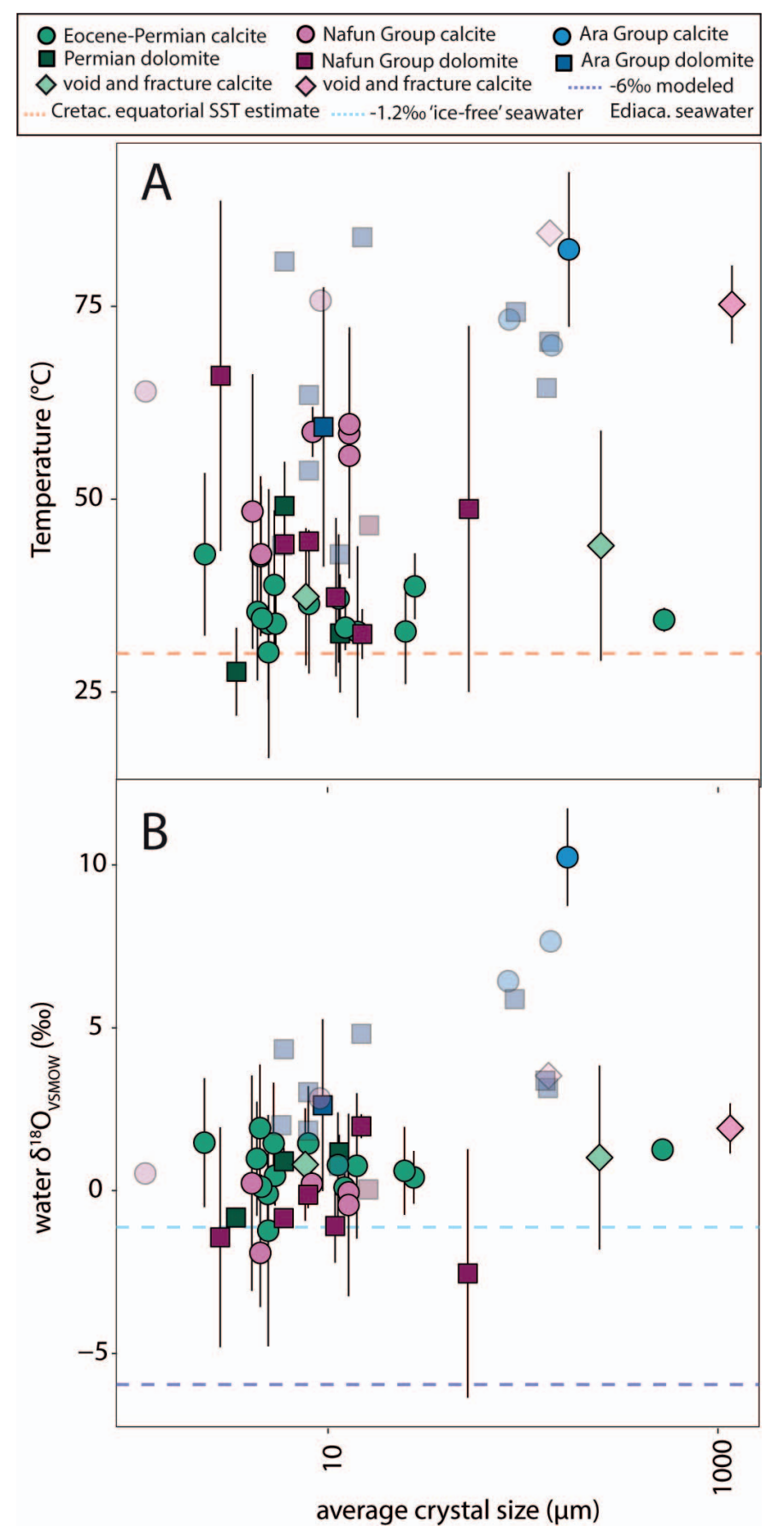

FIG. 7.-A) Average crystal size based on weighted area measurements of crystal sizes of grains, matrix, and cement versus $\Delta_{47}$ temperature for 50 samples of Permian-Paleogene carbonates, Ara Group carbonates, and Nafun Group carbonates. $\Delta_{47}$ temperature results are from replicated samples (dark with $62 \mathrm{SE}$ error bars) and single analyses (transparent symbols with no error shown) for calcite (circles), secondary calcite spar cement (diamonds), and dolomite (squares). The orange dashed line is at $30^{\circ} \mathrm{C}$, an estimate for equatorial sea-surface temperatures in the Cretaceous and Eocene (Upchurch et al. 2015; Douglas et al. 2014; Lunt et al. 2012; Dunkley Jones et al. 2013). B) Average crystal size versus calculated water

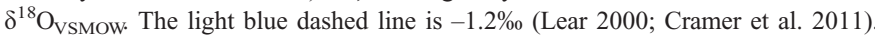
The dark blue dashed line is $-6 \%$, an Ediacaran seawater composition estimate assuming a constant climate state (Kasting et al. 2006; Veizer and Prokoph 2015; Jaffrés et al. 2007). fractures and voids is more common (HM1, HM3, HM4, HM7, HM8, HM9, HM10, HM11; Supplemental Materials). Secondary porosity enhancement has occurred in two of the three dolomitized samples in the Lower Khuff Formation (HM15, HM17, not HM14; Fig. 3E). The three dolomitized samples are uniformly composed of microspar with average crystal sizes between 4 and $12 \mu \mathrm{m}$ (Fig. 3E). Four samples of the equant mosaic cement endmember were analyzed from larger void- and fracturefilling cement pockets (HM2_2, HM5_2, HM7_2, HM8_2; Fig. 3B).

Clumped-isotope temperatures are surprisingly uniform across a range of petrographic textures and depths of the sampled Permian-Paleogene carbonates (Figs. 3, 6, 7). 20 of the 25 samples have clumped-isotope temperatures between 28 and $39^{\circ} \mathrm{C}$ (Table 1). The calcite samples are tightly clustered with a mean temperature of $36 \pm 3^{\circ} \mathrm{C}, 1 \mathrm{SD}, \mathrm{n}=18$ (Fig. 8, Table 5). The Permian Khuff Formation dolomite samples have an equivalent mean of $36 \pm 11^{\circ} \mathrm{C}, 1 \mathrm{SD}, \mathrm{n}=3$ (Fig. 8, Table 5). The endmember equant mosaic calcite spar samples are elevated on average (42 \pm $6^{\circ} \mathrm{C}, 1 \mathrm{SD}, \mathrm{n}=4$; Fig. 8 , Table 5). The clumped-isotope temperature of one void-filling equant mosaic calcite sample (HM5_2, $500.8 \mathrm{~m}$ depth) is equivalent to the current borehole temperature $\left(50 \pm 6^{\circ} \mathrm{C}, 2 \mathrm{SE}\right)$ and $17^{\circ} \mathrm{C}$ warmer than the host wackestone $\left(33 \pm 10^{\circ} \mathrm{C}, 2 \mathrm{SE}\right.$; Fig. 3B, Fig. 6).

\section{Ediacaran-Cambrian Ara Group}

The Ara Group samples are from 13 subsurface wells penetrating the South Oman Salt Basin and Central Oman High, from stratigraphy exposed in the Huqf outcrop area that has been correlated with the Ara Group but lacks evidence for significant evaporite deposition and from the Qarn Alam Salt Dome that sources the Ghaba Salt Basin (Figs. 1, 2). The Ara Group samples from the same well as the Permian-Paleogene samples (HM19-21 from $3148.7 \mathrm{~m}$ to $3180.5 \mathrm{~m}$ depth) are limestone samples from the Dhahaban Formation (Fig. 4A, B, C). HM19-21 have undergone significant dissolution and reprecipitation. They are currently coarse calcite cement with average crystal sizes from 85 to $171 \mu \mathrm{m}$. The samples contain significant amounts of anhydrite in-filling around carbonate crystals. Other Ara Group samples are similarly composed of coarse cement, whether calcite or dolomite (A4C_40_2, SBSB_2398_78, SBSB_2461_75, A.CS 92-136 $\mu \mathrm{m}$; Fig. 4D, E). This trend is common but is not consistent across all Ara Group samples (Figs. 4F, 7).

The three samples of coarse calcite cement from the Ara Group from well HM that underlie the Phanerozoic samples (3148.7-3180.5 m) are distinctive in that their clumped-isotope temperatures are higher than the Permian-Paleogene carbonates $\left(70 \pm 4^{\circ} \mathrm{C}, 82 \pm 10^{\circ} \mathrm{C}, 73 \pm 4^{\circ} \mathrm{C}, 2 \mathrm{SE}\right)$, and they agree with present-day borehole temperatures (Fig. 6; Table 2). Other subsurface samples analyzed from carbonate "stringers" from various depths in Central Oman and the South Oman Salt Basin yield similarly warm carbonate clumped isotope temperatures, broadly reproducing the current geotherm (Figs. 6, 7, 8). The mean clumped-isotope temperature of Ara Group calcites is $81 \pm 11^{\circ} \mathrm{C}, 1 \mathrm{SD}, \mathrm{n}=14$. Ara Group dolomite samples have a similar mean temperature of $72 \pm 12^{\circ} \mathrm{C}, 1 \mathrm{SD}, \mathrm{n}=$ 42 (Fig. 8; Table 5).

\section{Ediacaran Nafun Group}

The Nafun Group sample suite is from three subsurface wells (MQ, SWN, TM6) and the Huqf Outcrop Area (MD, KD; Figs. 1, 2). The Huqf outcrop samples are from a range of lithofacies and depositional environments, whereas most of the Nafun Group samples from subsurface wells are cuttings and cannot be assigned to lithofacies. In all sampling localities, the dolomite samples are from the Khufai and Buah Formations and the limestone samples are from the lowermost Khufai and Buah formations and the siliciclastic-dominated Shuram Formation (Fig. 1). The dolomitized Nafun samples show excellent fabric preservation, whether a mudstone or a stromatolite (Fig. 5A-E). Of the 17 calcite and dolomite 


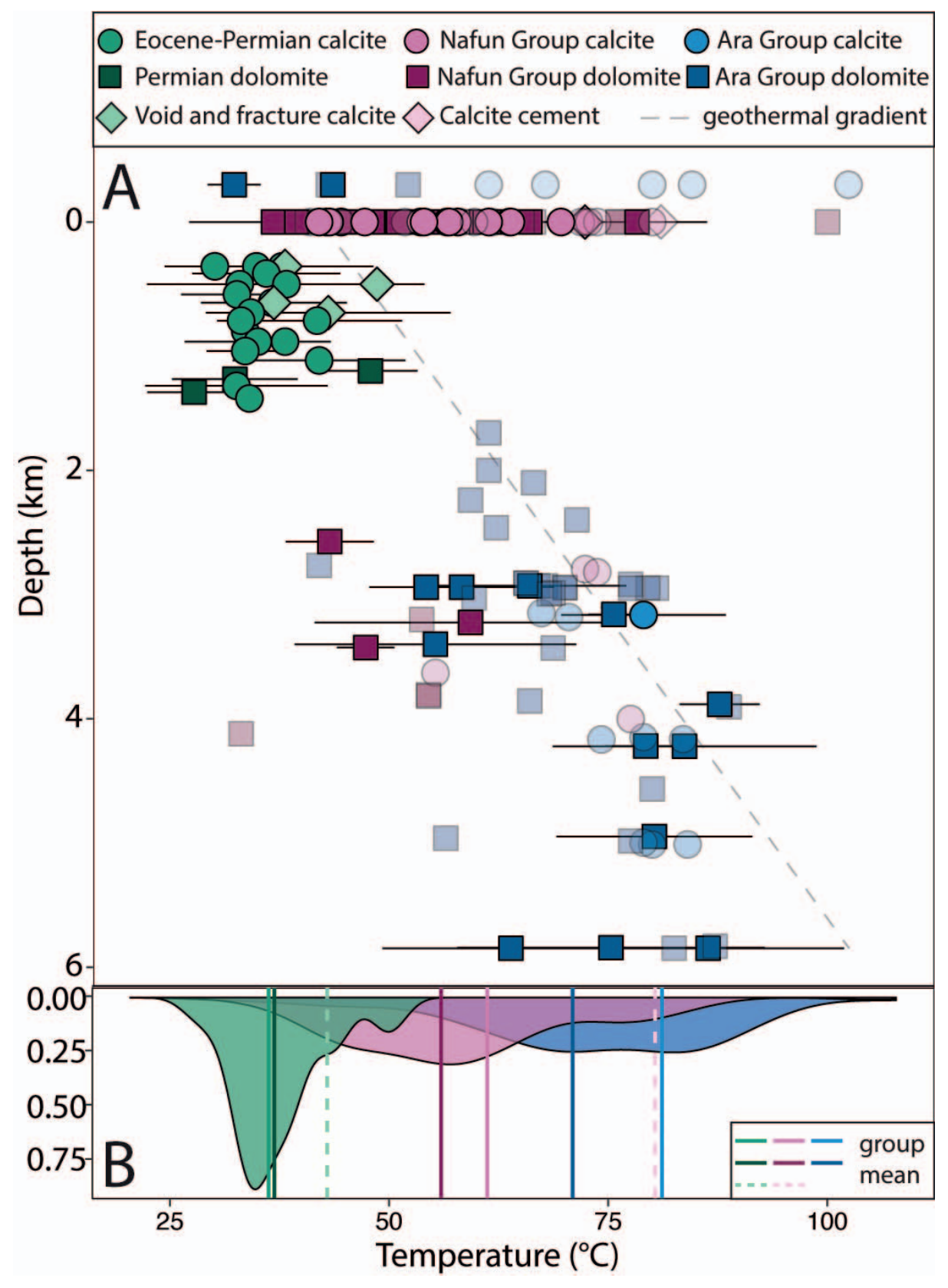

FIG. 8.-A) $\Delta_{47}$ temperature versus current burial depth for Central and South Oman for Permian-Paleogene samples (greens), EdiacaranCambrian samples from the Ara Group (blues), and Ediacaran samples from the Nafun Group (pinks). $\Delta_{47}$ temperature results are from replicated samples (dark with \pm 2SE error bars) and single analyses (transparent symbols with no error shown) for calcite (circles), calcite spar cement (diamonds), and dolomite (squares). A generalized South Oman Salt Basin geothermal gradient from borehole temperature measurements is shown with the dashed line (Schoenherr 2007) The Permian-Paleogene carbonates yield the lowest temperatures whereas the Ara Group carbonates sit near the modern geothermal gradient. Samples with zero depth are from outcrop exposures and are split into Nafun Group samples and Ara Group samples for clarity. B) A kernel density estimate for the three groups is plotted with vertical lines denoting the population means from Table 5 for calcite, dolomite, and cement for each group. samples examined petrographically, all but three have average crystal sizes between 3 and $15 \mu \mathrm{m}$. Some dolomitized facies retain primary intergranular porosity, including fenestral mudstones and oolites (Supplemental Materials). The Lower Khufai Formation is the only part of the stratigraphy in the Huqf outcrop area with coarse calcite overgrowth cements with average crystal sizes 137-1172 $\mu \mathrm{m}$ (MD6_10_0_K1, MD6_10_0_K2; Fig. 5F).

Samples from the subsurface Nafun Group do not sit on the geotherm like the overlying Ara Group carbonates in the few wells of the Central Oman High and South Oman Salt Basin where both are penetrated; instead an inverse temperature profile is preserved (Figs. 6, 8). Nafun Group calcites have a lower mean temperature compared to the overlying Ara Group $\left(61 \pm 12^{\circ} \mathrm{C}, 1 \mathrm{SD}, \mathrm{n}=33\right.$; Fig. 8 , Table 5$)$. The coarse calcite spar cement in the Lower Khufai Formation from the Huqf outcrop area is the hottest sample at $85 \pm 4^{\circ} \mathrm{C}, 2 \mathrm{SE}$ (Fig. 5F). Nafun Group dolomites have a similar mean of $55 \pm 13^{\circ} \mathrm{C}, 1 \mathrm{SD}, \mathrm{n}=53$ to Nafun Group calcites (Fig. 8, Table 5). A few dolomite samples from the Huqf outcrop area preserve cooler temperatures, including a stromatolite of $33 \pm 3^{\circ} \mathrm{C}, 2 \mathrm{SE}$; SB1_CON, Fig. 5A; Table 3).

\section{Reconstructed Water $\delta^{18} \mathrm{O}$ Values}

Clumped-isotope temperatures and mineral $\delta^{18} \mathrm{O}$ values were used to calculate the precipitating water $\delta^{18} \mathrm{O}$ values of each carbonate texture sampled, assuming equilibrium precipitation with temperature-dependent fractionation factors from Kim and O'Neil (1997) for calcite and Horita (2014) for dolomite (see Supplemental Materials for comparison of other dolomite fractionation equations).

In the Phanerozoic calcites, mean reconstructed water $\delta^{18} \mathrm{O}_{\text {vSMOw }}$ value is $0.6 \pm 0.7 \%, 1 \mathrm{SD}, \mathrm{n}=18$. The calcite spar cement has a mean water 


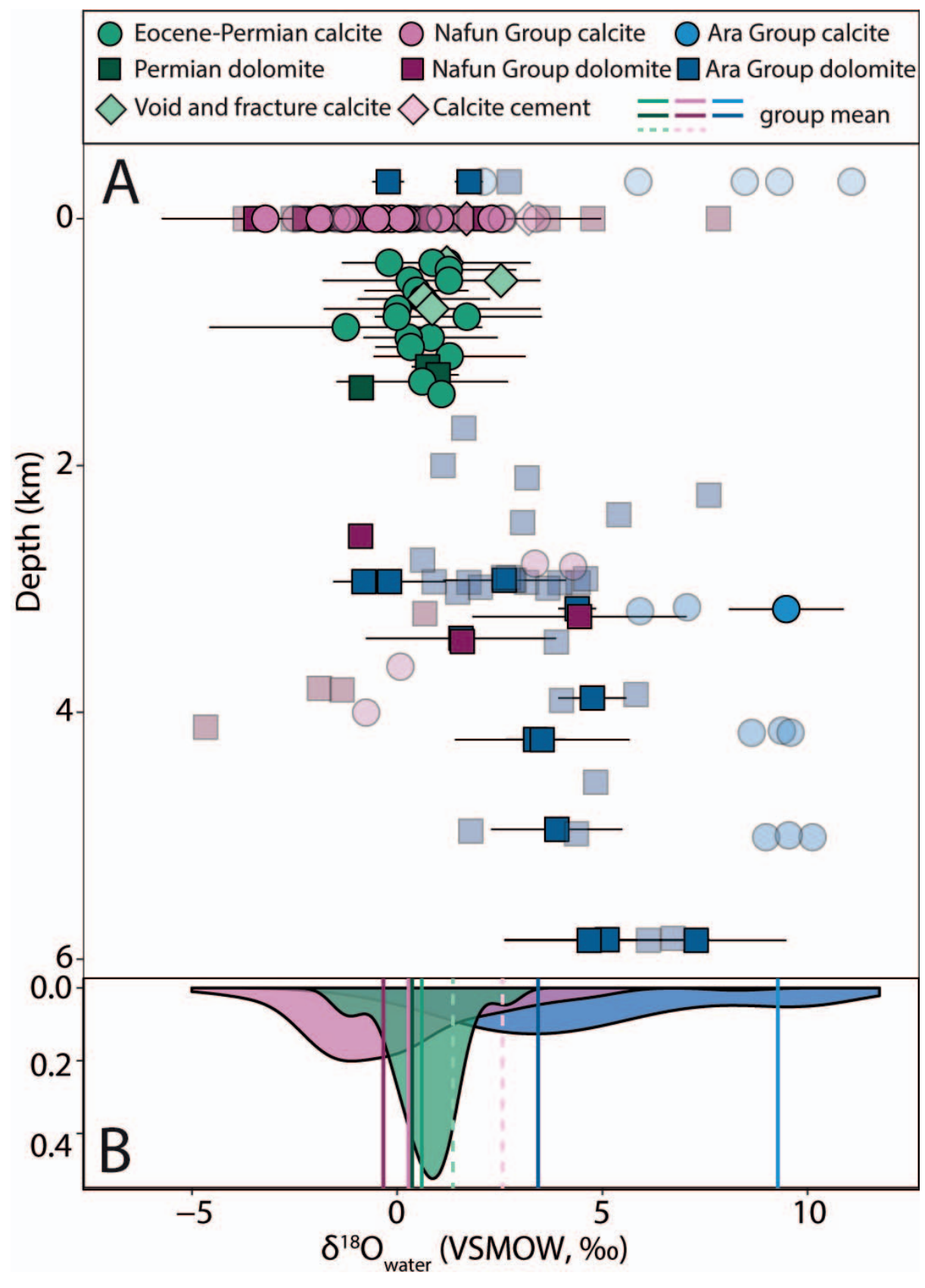

FIG. 9.-A) Water $\delta^{18} \mathrm{O}_{\text {VSMow }}$ versus presentday burial depth for Central and South Oman for Permian-Paleogene samples (greens), EdiacaranCambrian samples from the Ara Group (blues), and Ediacaran samples from the Nafun Group (pinks). Water $\delta^{18} \mathrm{O}_{\mathrm{VSMOW}}$ are from replicated samples (dark with $\pm 2 \mathrm{SE}$ error bars) and single analyses (transparent symbols with no error shown) for calcite (circles), secondary calcite spar cements (diamonds), and dolomite (squares). Both the Permian-Paleogene carbonates and the Nafun Group carbonates yield water $\delta^{18} \mathrm{O}_{\mathrm{VSMOW}}$ compositions of $\sim 0 \%$. The Ara Group carbonates yield enriched fluid compositions. Samples with zero depth are from outcrop exposures and are split into Nafun Group samples and Ara Group samples for clarity. B) A kernel density estimate for the three groups is plotted with vertical lines denoting the population means from Table 5 for calcite, dolomite, and cement for each group.

\section{DISCUSSION}

$\delta^{18} \mathrm{O}_{\text {vSMOw }}$ value of $1.4 \pm 0.9 \%, 1 \mathrm{SD}, \mathrm{n}=4$. Permian dolomites have mean reconstructed water $\delta^{18} \mathrm{O}_{\mathrm{VSMOW}}$ value of $0.3 \pm 1.1 \%, 1 \mathrm{SD}, \mathrm{n}=3$ (Fig. 9; Table 5).

In contrast to the Permian-Paleogene samples, Ara Group samples have more enriched reconstructed fluid compositions. Calcite samples have a mean reconstructed water $\delta^{18} \mathrm{O}_{\mathrm{VSMOW}}$ value of $8.8 \pm 2.5 \%, 1 \mathrm{SD}, \mathrm{n}=14$. Replicated dolomite samples have a mean water $\delta^{18} \mathrm{O}_{\mathrm{VSMOW}}$ value of 3.6 $\pm 2 \%$, 1SD, $\mathrm{n}=42$ (Fig. 9; Table 5).

Nafun Group carbonate reconstructed water $\delta^{18} \mathrm{O}_{\text {Vsmow }}$ values are distinct from those of the Ara Group. The replicated calcites have a mean reconstructed water $\delta^{18} \mathrm{O}_{\mathrm{VSMO}}$ value of $0.3 \pm 2 \%$, $1 \mathrm{SD}, \mathrm{n}=33$. The calcite-spar-cement water $\delta^{18} \mathrm{O}_{\mathrm{VSMO}}$ is heavier relative to other calcites with a value of $2.6 \pm 1.1 \%$, $1 \mathrm{SD}, \mathrm{n}=2$. Nafun Group dolomites have a mean reconstructed water $\delta^{18} \mathrm{O}_{\mathrm{VSM}}$ value of $-0.2 \pm 2.3 \%$, $1 \mathrm{SD}, \mathrm{n}=53$ (Fig. 9; Table 5).
Carbonate diagenesis can obscure the record of depositional conditions preserved in carbonates, through modification of fabrics and stable-isotope composition. When petrographic analysis and traditional stable isotopes are combined with clumped-isotope analyses, however, the range of fluid compositions and temperatures of carbonate precipitation provide additional information about the burial history of the carbonate rocks (Fig. 10). Interpretation of both depositional and diagenetic processes can be complicated in deeply buried carbonates by the potential for solid-state reordering of $\mathrm{C}-\mathrm{O}$ bonds in carbonate minerals.

\section{Solid-State Reordering}

In high-temperature deep-burial environments, the carbonate clumpedisotope thermometer can be affected by "solid-state bond reordering" 


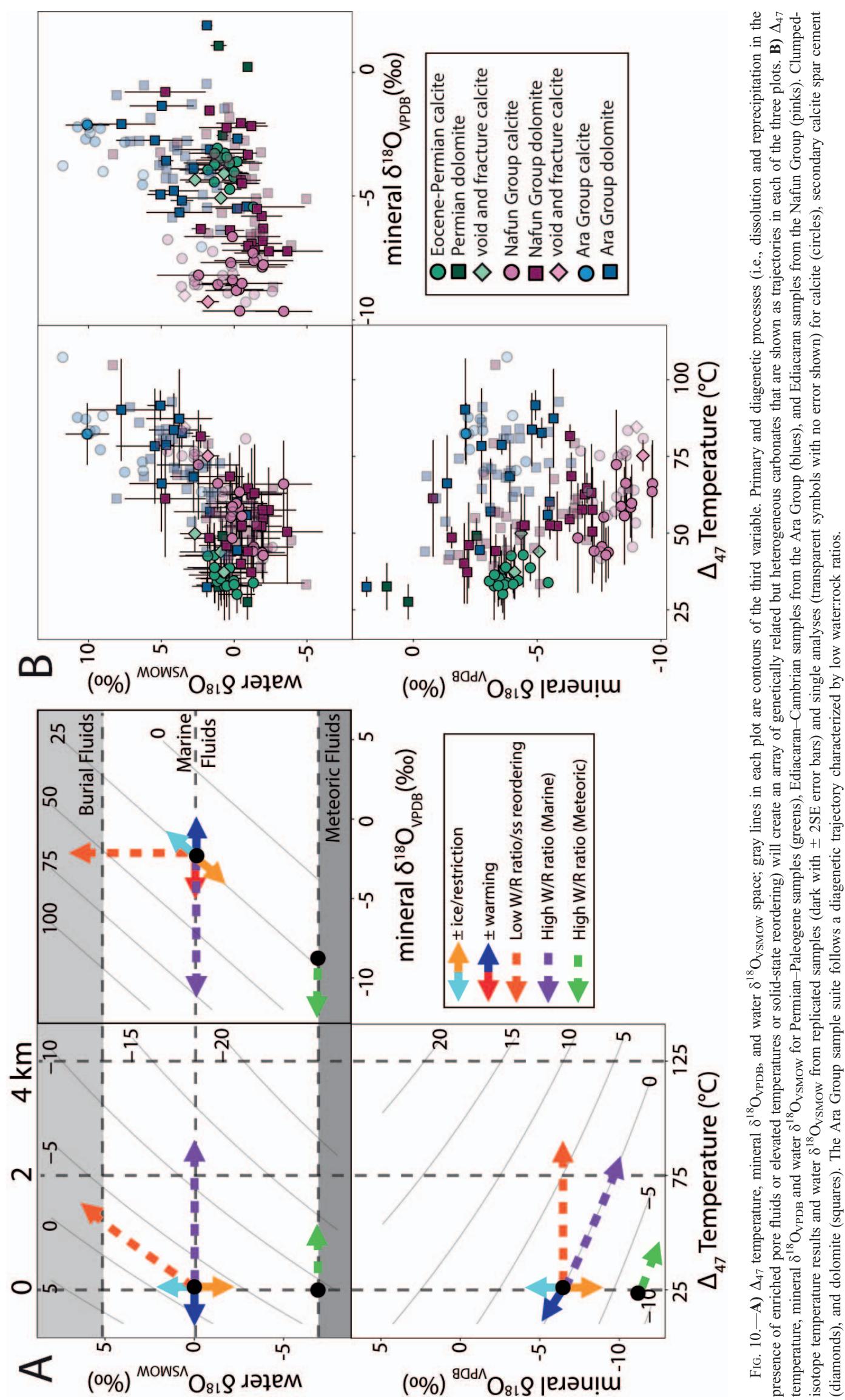




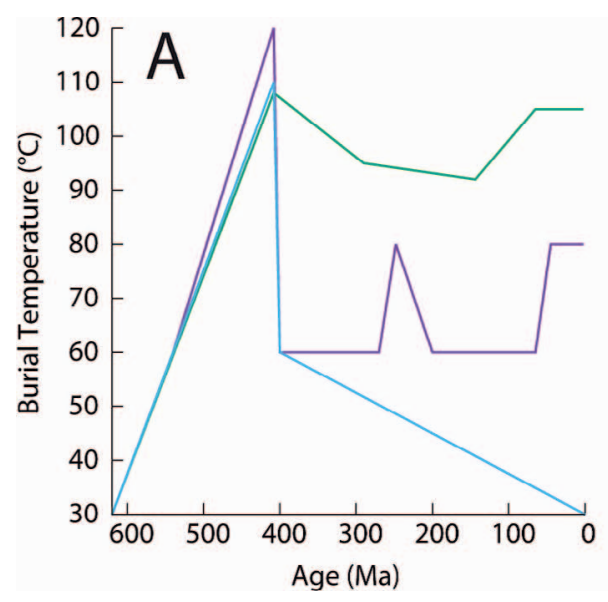

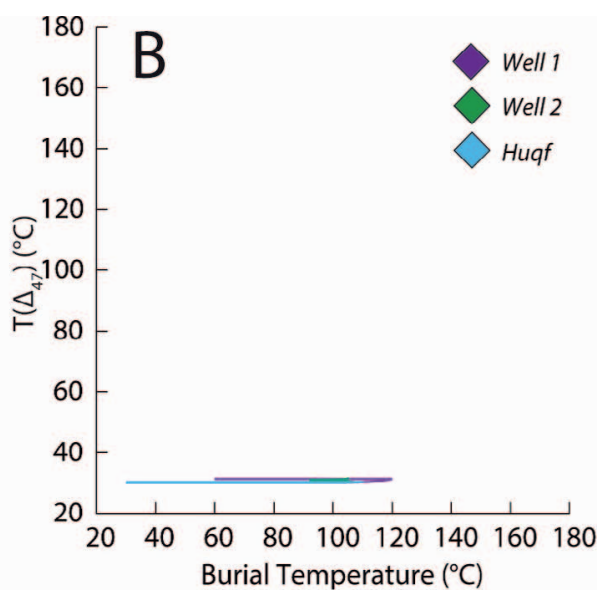

FIg. 11.-A) Time-temperature burial histories for three locations, Well 1, Well 2, and the Huqf outcrop area from Visser (1991). B) Modeled change in $\Delta_{47}$ temperature resulting from solidstate reordering in calcite from temperature histories for Well 1, Well 2, and the Huqf using model from Henkes et al. (2014). Results indicate $<5^{\circ} \mathrm{C}$ temperature change. driven by isotopic exchange without dissolution and reprecipitation of new carbonate cements (Dennis and Schrag 2010; Passey and Henkes 2012; Henkes et al. 2014; Stolper and Eiler 2015). Solid-state reordering is thought to progress through two processes: heating experiments show initial rapid partial equilibration at high temperatures followed by slow continued equilibration (Henkes et al. 2014; Stolper and Eiler 2015). Models that have been proposed for the initial rapid equilibration phase include propagation of dislocations, akin to physical annealing, or through nearest-neighbor pair substitutions (Henkes et al. 2014; Stolper and Eiler 2015). This more rapid process initially dominates over diffusion, which governs the rate of continued equilibration in the slow phase (Henkes et al. 2014; Stolper and Eiler 2015). Because solid-state reordering depends on crystal structure and bond strength, different minerals have different thresholds for solid-state reordering (Stolper and Eiler 2015). In minerals accessible to the carbonate clumped-isotope thermometer, experimental work suggests that reordering occurs at temperatures $>115^{\circ} \mathrm{C}$ over $10^{6}$ to $10^{8}$ years for calcite (Henkes et al. 2014; Stolper and Eiler 2015); dolomite does not reorder at temperatures up to $200^{\circ} \mathrm{C}$ over $10^{8}$ years (Lloyd et al. 2017). While these reordering temperatures have been determined based on high-temperature heating experiments, few studies fully constrain the point at which solid-state reordering begins to occur in the shallow-burial environment (Quade et al. 2013; Winkelstern and Lohmann 2016; Murray and Swart 2017).

Given the different susceptibilities of calcite and dolomite to solid-state reordering, we would expect calcite and dolomite samples to diverge in temperature if solid-state reordering is an important process acting on these clumped-isotope temperatures. In this case, calcite samples would be warmer than co-occurring dolomite samples if they both were precipitated during early burial. We do not see this behavior in the Phanerozoic, Ara, or Nafun group carbonates (Fig. 8).

Independent evidence for low burial temperatures from organic maturity (Visser 1991) provide a test for potential solid-state reordering in these carbonate sections. Burial-temperature histories for wells 1 and 2 and the Huqf outcrop area from Visser (1991) were used to model the degree of solid-state reordering (Fig. 11; Henkes et al. 2014); results indicate that solid-state reordering should lead to a $0-5 \%$ change in calcite clumped-isotope temperatures, which translates to an apparent temperature change of $<2^{\circ} \mathrm{C}$ for Nafun and Ara Group calcite samples from solid-state reordering. The suppressed geothermal gradient in the region yields $100^{\circ} \mathrm{C}$ temperatures at depths of 4-6 km; low temperature at depth complicates predicting the thermal history of exhumed carbonates.

The lack of mineralogy-specific temperature divergence combined with model predictions from kinetics of calcite $\mathrm{C}-\mathrm{O}$ bond reordering indicate that neither the Phanerozoic nor the Ediacaran carbonate clumped-isotope temperatures were likely affected by solid-state reordering. Differences in temperatures among Oman carbonates sampled in this study are accordingly a product of precipitation temperatures, whether in the depositional or the burial environment from processes that include cementation, dolomitization, dissolution, and reprecipitation.

\section{Temperature, Timing, and Fluid Composition of Diagenetic Modification}

Permian-Paleogene Carbonates.-Petrographically, Permian-Paleogene carbonates display a range of diagenetic fabrics. Many, but not all, of the primary fossil shells have either been dissolved and replaced by equant mosaic calcite cement or micrite. The intergranular porosity in the majority of samples has been occluded with clear blocky calcite cement.

The clumped-isotope temperatures are consistent over $1.5 \mathrm{~km}$ of burial despite significant variability in both primary fabric and postdepositional fabric modification (Figs. 6, 8, Table 5). Phanerozoic samples show minor enrichment of their water $\delta^{18} \mathrm{O}$ values $(0-2 \%)$ relative to a predicted icefree seawater value of $-1.2 \%$ (Figs. 7, 12; Tables 1, 5; Lear 2000; Cramer et al. 2011). This indicates that the fluids driving cementation remained seawater-like in composition from deposition through burial and cementation. A higher water:rock ratio diagenetic pathway is supported by the behavior of the entire population in $\Delta_{47}$ temperature, mineral $\delta^{18} \mathrm{O}_{\mathrm{VPDB}}$, and water $\delta^{18} \mathrm{O}_{\mathrm{VS}}$ ow space (Fig. 10). Similar results have been reported for drill cores from the Bahamas, where carbonates yield clumped-isotope temperatures $<10^{\circ} \mathrm{C}$ above modern sea-surface values up to $1.3 \mathrm{~km}$ depth despite pervasive dissolution, reprecipitation, and cementation by $250 \mathrm{~m}$ depth (Winkelstern and Lohmann 2016). Together, our results of clumped-isotope temperatures $0-15^{\circ} \mathrm{C}$ above estimates of Eocene-Cretaceous equatorial sea-surface temperature of $\sim 30^{\circ} \mathrm{C}$ (Huber and Sloan 2001; Lunt et al. 2012; Dunkley Jones et al. 2013; Douglas et al. 2014; Upchurch et al. 2015) and 24 of 25 Permian-Paleogene carbonates within $0-3 \%$ of "ice-free" seawater compositions suggest that dissolution, reprecipitation, and cementation occurred during shallow burial within tens of meters of the seafloor (Figs. 7, 12, Table 1).

Ediacaran-Cambrian Ara Group.- In contrast to the open-systemlike results for Permian-Paleogene samples, the relationships among temperature, mineral $\delta^{18} \mathrm{O}_{\mathrm{VPDB}}$, and water $\delta^{18} \mathrm{O}_{\mathrm{VSMOW}}$ of the Ara Group carbonates indicates that these rocks have undergone dissolution and reprecipitation in environments with low water:rock ratios (Fig. 10). These are the only carbonates with clumped-isotope temperatures that match current measured borehole temperatures (Figs. 6, 8), indicating that dissolution and reprecipitation or increases in crystal size continued to occur during deeper burial. 


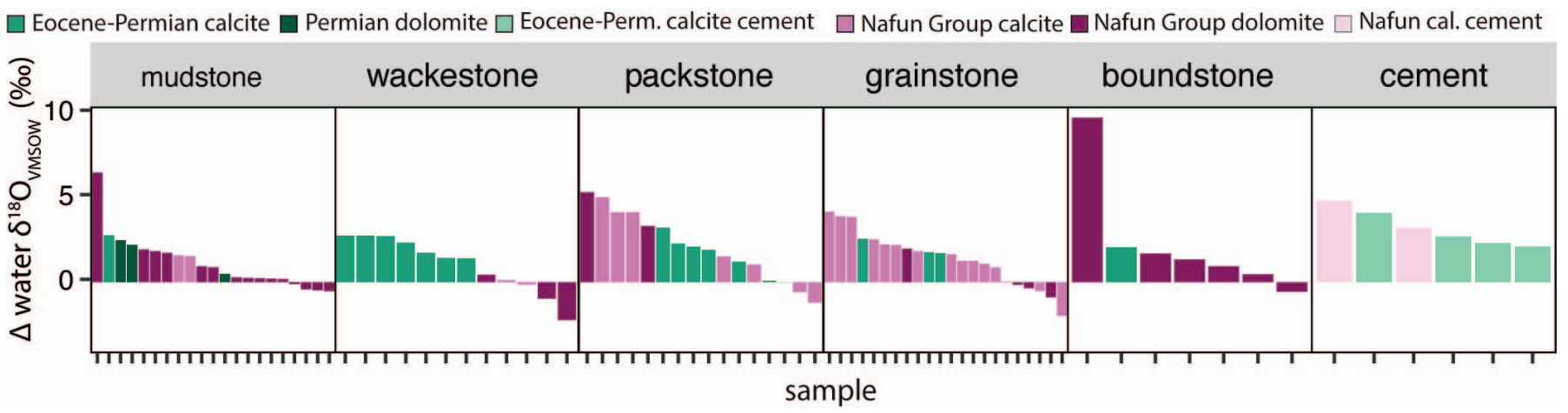

FIG. 12.-Difference between reconstructed $\delta^{18} \mathrm{O}_{\text {VSMOw }}$ water values and -1.2\% the value predicted for modern "ice-free" seawater (Lear 2000; Cramer et al. 2011) for Permian-Paleogene carbonates (greens) and Nafun Group carbonates (pinks) separated using the Dunham classification.

Two components of the Ara Group carbonate depositional environment likely contribute to their diagenetic and clumped-isotope character: organic maturation and the co-occurrence with depositional evaporites. The Ara Group is a self-sourcing microbial oil reservoir (Grosjean et al. 2009, 2012), and these carbonates accordingly experienced organic maturation reactions in the course of diagenesis. Organic maturation reactions are typically acidic (Seewald 2003), and maturation in the salt "stringers" with low water:rock ratios would have promoted dissolution and reprecipitation of the Ara Group carbonates with burial (e.g., Heydari and Wade 2002). All of the Ara Group carbonates are either interbedded with thinner salt horizons or float as "stringers" within the main salt bodies (Fig. 2). Saltbody permeability and porosity are very low (Casas and Lowenstein 1989), and this low permeability and porosity affects fluid flow through carbonate stringers. Thus, dissolution and reprecipitation of carbonate stringers would have occurred in a rock-buffered diagenetic environment, with possible contribution of enriched fluids from the gypsum-anhydrite transformation during burial. Such closed-system alteration is consistent with the narrow range of mineral $\delta^{18} \mathrm{O}$ values found in the Ara Group carbonates (Table 3). Rock-buffered mineral $\delta^{18} \mathrm{O}$ values combined with high temperatures of dissolution and reprecipitation yield enriched reconstructed $\delta^{18} \mathrm{O}$ fluid values (Fig. 9). The clumped-isotope temperatures and reconstructed $\delta^{18} \mathrm{O}$ fluid values of this unit provide a window into diagenetic processes associated with mixed carbonate-evaporite deposition and diagenetic alteration with low water:rock ratios during burial.

Ediacaran Nafun Group.-Petrographically, the Nafun Group carbonates are equivalent to or have better textural preservation than the Permian-Paleogene carbonates, with excellent preservation of fine crystal sizes, primary grains including ooids and pisoids with early fibrous cements, evidence for early cementation, and preserved primary porosity in some dolomite grainstones, fenestral mudstones, and crinkly laminites (Figs. 5, 7, Table 4; Supplemental Materials). Some coarse calcite cements have undergone dissolution and reprecipitation at higher temperatures in the Lower Khufai Formation associated with a fetid-limestone interval (MD6_10_0_K1, MD6_10_0_K2; Fig. 5F).

In the Nafun Group samples, calcite and dolomite $\Delta_{47}$ temperatures are similar to each other and are intermediate between Permian-Paleogene clumped-isotope temperatures and Ediacaran-Cambrian Ara Group clumped-isotope temperatures. In the wells containing both Ara Group and underlying Nafun Group carbonates, an inverse temperature stratigraphy is preserved, with Nafun Group carbonates yielding lower $\Delta_{47}$ temperatures than the overlying Ara Group carbonates (Fig. 6, MQ, SWN). Reconstructions of fluid values of 59 of 94 Nafun Group calcites and dolomites are within $0-3 \%$ of estimates of "ice-free" seawater (Figs. 7, 9, 12, Table 3, Supplemental Materials), and 81 of 94 carbonates are within $-1-4 \%$ of estimates of "ice-free" seawater (which has been estimated between -0.89 and $-1.2 \%$, VSMOW; Lear 2000; Cramer et al. 2011). Reconstructed fluid $\delta^{18} \mathrm{O}$ values are thus consistent with petrographic preservation. Together, these data suggest that diagenetic modifications occurred in an environment similar to that of the PermianPaleogene carbonates, within tens of meters of the seafloor, which magnifies the temperature discrepancy between the Nafun Group and Permian-Paleogene populations.

\section{Stratigraphic Variation of Clumped Isotope Temperature}

The $\sim 20^{\circ} \mathrm{C}$ temperature difference between the population means of the Permian-Paleogene carbonates and the Nafun Group is striking. This difference can be explained in one of two ways: through major differences in the diagenetic processes that affected the two groups, or through a primary shift in Earth's mean climate state.

The stratigraphic temperature change is superficially similar to that of Bahamian cores studied by Winkelstern and Lohmann (2016). In these Bahamian cores, carbonates below $1.3 \mathrm{~km}$ increased in clumped-isotope temperatures by approximately $10-30^{\circ} \mathrm{C}$. Like the Oman sections in this study, the shift in temperatures was shared by both calcites and dolomites, though the highest temperatures were recorded in dolomites. Winkelstern and Lohmann (2016) ascribed this shift to alteration with burial, despite moderate burial depths. Increasing temperatures in the Bahamian cores are, however, accompanied by enrichment of reconstructed fluid $\delta^{18} \mathrm{O}$ values exceeding $+4 \%$ VSMOW (Winkelstern and Lohmann 2016), consistent with diagenetic models calling on interactions between carbonates and migrating seawater modified by evaporation (Murray and Swart 2017). Nafun Group carbonates lack a similar enrichment in reconstructed fluid composition. Unlike the Nafun Group carbonates, petrographic textures in the Bahamian cores also show later growth of dolomites in the subsurface with progressive replacement of original carbonate textures with microcrystalline dolomite rhombs. In this case, dissolution and reprecipitation would skew the carbonates toward conditions associated with burial. Such an association of dissolution and reprecipitation during deeper burial is more consistent with trends observed in the Ara Group salt "stringers" with lower water:rock ratios than the Nafun Group carbonates (Fig. 10). The coarse crystal size of many Ara Group carbonates is similar to the textures described in the Bahamian cores of Winkelstern and Lohmann (2016). In contrast to the Bahamian or Ara Group carbonates, both calcites and dolomites of the Nafun Group maintain fabric-retentive textures (including both ooids and mudstones) and lack evidence for deeper-burial dissolution and reprecipitation (Fig. 7).

A second diagenetic possibility exists, that the tectonic deformation associated with the large-scale folding of the Nafun Group stratigraphy in the Huqf outcrop area reset clumped-isotope temperatures of both the Ara Group and Nafun Group soon after deposition of the Ara Group (Ries and 
Shackleton 1990; Gorin et al. 1982). In this model, the Ara Group alone has continued to reset towards the modern geotherm. Both diagenetic possibilities, deeper-burial diagenesis or tectonic resetting, cannot be discounted based on the work presented here. It is important to note that if the temperatures have been reset during cryptic diagenesis associated with deeper burial or tectonic activity, with no petrographic evidence for large crystal sizes or alteration of other thermal maturity indicators like biomarker preservation (Love et al. 2009), the reconstructed values that match estimates "ice-free" seawater-like $\delta^{18} \mathrm{O}$ values are purely coincidental (Figs. 7, 9, 12).

An alternative model to explain higher Nafun Group $\Delta_{47}$ temperatures is an evolution of Earth's mean climate state. This interpretation is supported by several lines of evidence. The overlapping reconstructed fluid $\delta^{18} \mathrm{O}$ compositions are similar to "ice-free" seawater for both calcite and fabricretentive dolomite despite their different behaviors during diagenesis and burial. These fluid reconstructions are consistent across a range of fabrics, including mudstones, stromatolites, and oolites (Figs. 5, 7, 12). Furthermore, burial constraints from other proxies do not indicate conditions relevant for solid-state reordering (Visser 1991; Grosjean et al. 2009; Love et al. 2009). Our Ediacaran results from Oman are also in agreement with other clumped-isotope studies from the Phanerozoic that indicate no change in "ice-free" seawater composition from shallowly buried, well-preserved carbonates and apatites (Came et al. 2007; Finnegan et al. 2011; Bergmann et al. 2018; Henkes et al. 2018). Finally, such seawater $\delta^{18} \mathrm{O}$ reconstructions agree with an independent reconstruction of Neoproterozoic seawater $\delta^{18} \mathrm{O}$ value of $-1.33 \%$ from fossil black smokertype abyssal hydrothermalism (Hodel et al. 2018). While the results from one location will not conclusively solve the decades-long debate about Precambrian-early Phanerozoic climate and seawater composition (Knauth and Lowe 2003; Kasting et al. 2006; Robert and Chaussidon 2006; Jaffrés et al. 2007; Gaucher et al. 2008; Veizer and Prokoph 2015), based on the above evidence from the Ediacaran Nafun Group of Oman we argue our data does not support the evolution of seawater $\delta^{18} \mathrm{O}$ values over the last 600 million years to $\delta^{18} \mathrm{O}$ values as depleted as $-6 \%$ VSMOW in the Ediacaran accommodated by changes in hydrothermal cycling at midocean ridges (Kasting et al. 2006; Jaffrés et al. 2007; Veizer and Prokoph 2015). We suggest that it is worth reassessing with new methods, observations, and models whether there is evidence for a major change in Earth's climate system across the Neoproterozoic to Ordovician, a critical period in the history of complex life on Earth.

\section{CONCLUSIONS}

In combination with petrographic characterization, carbonate-clumped isotope thermometry provides a tool to untangle the timing, temperature, and fluid composition of depositional and postdepositional processes for a given succession. In agreement with experimental studies, our clumpedisotope temperatures for two mineralogies, both calcite and dolomite, indicate that solid-state reordering is not a dominant process in shallowburial environments on long geologic timescales.

We find evidence for two broad patterns in the physical and geochemical behavior of carbonate rocks during shallow burial. Both PermianPaleogene carbonates and Ediacaran Nafun Group carbonates yield water $\delta^{18} \mathrm{O}_{\text {VSMOW }}$ values slightly enriched or equal to expected "ice-free" seawater composition of $-1.2 \%$ and display good to fair textural preservation, suggesting cementation, lithification, and any dissolution and reprecipitation occurred within tens of meters of the sediment-water interface. Permian-Paleogene clumped-isotope temperatures of lithified rocks are $0-15^{\circ} \mathrm{C}$ above other proxy data for Permian-Paleogene seasurface temperatures. On average, Nafun Group lithified carbonates are $20^{\circ} \mathrm{C}$ warmer that lithified Permian-Paleogene carbonates. The Ara Group, a self-sourcing petroleum reservoir, is a second diagenetic end-member. Clumped-isotope temperatures match the present-day geotherm, water $\delta^{18} \mathrm{O}_{\mathrm{VSMOW}}$ values are very enriched, and textural preservation is fair to poor. We implicate organic degradation and the gypsum to anhydrite phase transition as important in the diagenetic history of Ara Group carbonates.

Our results from a 600-million-year record from Oman are inconsistent with seawater $\delta^{18} \mathrm{O}$ values of $-6 \%$ in the Ediacaran and suggest that Ediacaran depositional environments may have been warmer than their Phanerozoic counterparts. It is impossible to fully discount the potential importance of 600 million years of geologic time and the role of cryptic diagenesis in resetting of the clumped-isotope temperature of Nafun Group carbonates. That said, the results from this study yielding expected "icefree" seawater $\delta^{18} \mathrm{O}$ values of $-1.2 \%$ for both Nafun Group calcites and dolomites across a range of burial environments can be tested against data from other shallowly buried Precambrian locations to better reconstruct the Precambrian climate system.

\section{SUPPLEMENTAL MATERIALS}

Supplemental files are available from JSR's Data Archive: https://www.sepm. org/pages.aspx?pageid $=229$.

\section{ACKNOWLEDGMENTS}

We thank two anonymous reviewers, Bruce Wilkinson, and John Southard for providing helpful comments. We would like to thank the Ministry of Oil and Gas of the Sultanate of Oman for permission to access samples and for publication permission. Petroleum Development Oman contributed field logistical support, subsurface sample access, and borehole temperature data. We thank Gideon Lopes Cardozo, Zuwena Al Rawahi, Joachim Amthor, Irene Gomez-Perez, Gordon Forbes, and Aly Brandenburg from Petroleum Development Oman in particular for supporting many aspects of this project. We would like to thank Maggie Osburn and Jena Johnson for fieldwork assistance related to sampling the Nafun Group in the Huqf outcrop area. Outcrop samples from Qarn Alam salt dome were provided by Said Al Balushi and Monique Mettraux. We would also like to thank Nami Kitchen, Chi Ma, and Nick Boekelheide for analytical assistance. A National Science Foundation Graduate Research Fellowship was provided to K. Bergmann. The Agouron Institute and the MIT node of the NASA Astrobiology Institute contributed to analytical costs.

\section{REFERENCES}

Allen, P.A., 2007, The Huqf Supergroup of Oman: basin development and context for Neoproterozoic glaciation: Earth-Science Reviews, v. 84, p. 139-185, doi: 10.1016/j. earscirev.2007.06.005

AL-SIYABI, H.A., 2005, Exploration history of the Ara intrasalt carbonate stringers in the South Oman Salt Basin: GeoArabia, v. 10, p. 39-72.

Bendias, D., And Aigner, T., 2015, Facies, sequence stratigraphy, reservoir and seal potential of the Mafraq Formation, Sultanate of Oman: an integrated outcrop analogue study: GeoArabia, v. 20, p. 17-94.

Bergmann, K.D., Finnegan, S., Creel, R., Eiler, J.M., Hughes, N.C., Popov, L.E., And Fischer, W.W., 2018, A paired apatite and calcite clumped isotope thermometry approach to estimating Cambro-Ordovician seawater temperatures and isotopic composition: Geochimica et Cosmochimica Acta, v. 224, doi: 10.1016/j.gca.201 7.11.015.

Bernasconi, S.M., Hu, B., Wacker, U., Fiebig, J., Breitenbach, S.F.M., and RutZ, T., 2013, Background effects on Faraday collectors in gas-source mass spectrometry and implications for clumped isotope measurements: Rapid Communications in Mass Spectrometry, v. 27, p. 603-612, doi: 10.1002/rcm.6490.

Bonifacie, M., Calmels, D., Eiler, J.M., Horita, J., Chaduteau, C., Vasconcelos, C., Agrinier, P., Katz, A., Passey, B.H., Ferry, J.M., and Bourrand, J.J., 2017, Calibration of the dolomite clumped isotope thermometer from 25 to $350{ }^{\circ} \mathrm{C}$, and implications for a universal calibration for all $(\mathrm{Ca}, \mathrm{Mg}, \mathrm{Fe}) \mathrm{CO}_{3}$ carbonates: Geochimica et Cosmochimica Acta, v. 200, p. 255-279, doi: 10.1016/j.gca.2016.11.028.

Bowring, S.A., Grotzinger, J.P., Condon, D.J., Ramezani, J., Newall, M.J., And Allen, P.A., 2007, Geochronologic constraints on the chronostratigraphic framework of the neoproterozoic Huqf Supergroup, Sultanate of Oman: American Journal of Science, v. 307, p. 1097-1145, doi: 10.2475/10.2007.01.

Brand, U., 2004, Carbon, oxygen and strontium isotopes in Paleozoic carbonate components: an evaluation of original seawater-chemistry proxies: Chemical Geology, v. 204 , p. $23-44$, doi: 10.1016/j.chemgeo.2003.10.013. 
Brand, W.A., Assonov, S.S., And Coplen, T.B., 2010, Correction for the ${ }^{17} \mathrm{O}$ interference in $\delta^{13} \mathrm{C}$ measurements when analyzing $\mathrm{CO}_{2}$ with stable isotope mass spectrometry (IUPAC Technical Report): Pure and Applied Chemistry, v. 82, p. 1719-1733, doi: 10.1351/PACREP-09-01-05.

Came, R.E., Eiler, J.M., Veizer, J., Azmy, K., Brand, U., and Weidman, C.R., 2007, Coupling of surface temperatures and atmospheric $\mathrm{CO}_{2}$ concentrations during the Palaeozoic Era: Nature, v. 449, p. 198-201, doi: 10.1038/nature06085.

CASAS, E., And Lowenstein, T.K., 1989, Diagenesis of salinte pan halite: comparison of petrographic features of modern, Quaternary, and Permian halites: Journal of Sedimentary Petrology, v. 59, p. 724-739, doi: 10.1306/212F905C-2B24-11D7$8648000102 \mathrm{C} 1865 \mathrm{D}$

Cozzi, A., Grotzinger, J.P., ANd Allen, P.A., 2004, Evolution of a terminal Neoproterozoic carbonate ramp system (Buah Formation, Sultanate of Oman): Effects of basemen paleotopography: Geological Society of America, Bulletin, v. 116, p. 1367-1384, doi: 10.1130/B25387.1

Cramer, B.S., Miller, K.G., Barrett, P.J., and Wright, J.D., 2011, Late CretaceousNeogene trends in deep ocean temperature and continental ice volume: reconciling records of benthic foraminiferal geochemistry $\left(\delta^{18} \mathrm{O}\right.$ and $\left.\mathrm{Mg} / \mathrm{Ca}\right)$ with sea-level history: Journal of Geophysical Research: Oceans, v. 116, C12023, doi: 10.1029/2011JC007255

Daëron, M., Blamart, D., Peral, M., and Affek, H.P., 2016, Absolute isotopic abundance ratios and the accuracy of $\Delta_{47}$ measurements: Chemical Geology, v. 442, p. 83-96, doi: 10.1016/j.chemgeo.2016.08.014

Defliese, W.F., Hren, M.T., and Lohmann, KC., 2015, Compositional and temperature effects of phosphoric acid fractionation on $\Delta_{47}$ analysis and implications for discrepant calibrations: Chemical Geology, v. 396, p. 51-60, doi: 10.1016/j.chemgeo.2014.12.018

DenNIS, K.J., AND Schrag, D.P., 2010, Clumped isotope thermometry of carbonatites as an indicator of diagenetic alteration: Geochimica et Cosmochimica Acta, v. 74, p. 4110 4122, doi: 10.1016/j.gca.2010.04.005.

Dennis, K.J., Affek, H.P., Passey, B.H., Schrag, D.P., And Eller, J.M., 2011, Defining an absolute reference frame for "clumped" isotope studies of $\mathrm{CO}_{2}$ : Geochimica et Cosmochimica Acta, v. 75, p. 7117-7131, doi: 10.1016/j.gca.2011.09.025.

Douglas, P.M.J., Affek, H.P., Ivany, L.C., Houben, A.J.P., SijP, W.P., Sluijs, A., Schouten, S., And Pagani, M., 2014, Pronounced zonal heterogeneity in Eocene southern highlatitude sea surface temperatures: Proceedings of the National Academy of Sciences [USA], v. 111, p. 1-6, doi: 10.1073/pnas.1321441111.

Dubreullh, J., Platel, J.P., Le Métour, J., Roger, J., Wyns, R., Béchennec, F., And Berthiaux, A., 1992, Explanatory notes to the Geological map of Khaluf, Sheet NF 4015 , scale $1: 250000$.

Dunkley Jones, T., Lunt, D.J., Schmidt, D.N., Ridgwell, A., Sluijs, A., Valdes, P.J., And MasLin, M., 2013, Climate model and proxy data constraints on ocean warming across the Paleocene-Eocene Thermal Maximum: Earth-Science Reviews, v. 125, p. 123-145, doi: 10.1016/j.earscirev.2013.07.004.

EILER, J.M., 2007, "Clumped-isotope" geochemistry: the study of naturally-occurring, multiply-substituted isotopologues: Earth and Planetary Science Letters, v. 262, p. 309 327, doi: 10.1016/j.eps1.2007.08.020.

EILER, J.M., 2011, Paleoclimate reconstruction using carbonate clumped isotope thermometry: Quaternary Science Reviews, v. 30, p. 3575-3588, doi: 10.1016/j.quas cirev.2011.09.001.

Fernandez, A., Tang, J., And Rosenheim, B.E., 2014, Siderite "clumped" isotope thermometry: a new paleoclimate proxy for humid continental environments: Geochimica et Cosmochimica Acta, v. 126, p. 411-421, doi: 10.1016/j.gca.2013.11.006.

Finnegan, S., Bergmann, K., Eiler, J.M., Jones, D.S., Fike, D.A., Eisenman, I., Hughes, N.C., Tripati, A.K., And Fischer, W.W., 2011a, The magnitude and duration of Late Ordovician-Early Silurian glaciation: Science, v. 331, p. 903-906, doi: 10.1126/sci ence. 1200803 .

Forbes, G.A., Janseni, H.S.M., And Schreurs, J., 2010, Lexicon of oman subsurface stratigraphy: GeoArabia, v. 15 , p. $210-215$.

Gaucher, E.A., Govindarajan, S., And Ganesh, O.K., 2008, Palaeotemperature trend for Precambrian life inferred from resurrected proteins: Nature, v. 451, p. 704-707, doi: 10.1038 /nature06510.

Gorin, G.E., Racz, L.G., and Walter, M.R., 1982, Late Precambrian-Cambrian sediments of Huqf Group, Sultanate of Oman: American Association of Petroleum Geologists, Bulletin, v. 66, p. 2609-2627.

Grosjean, E., Love, G.D., Stalvies, C., Fike, D.A., and Summons, R.E., 2009, Origin of petroleum in the Neoproterozoic-Cambrian South Oman Salt Basin: Organic Geochemistry, v. 40, p. 87-110, doi: 10.1016/j.orggeochem.2008.09.011.

Grosjean, E., Love, G.D., Kelly, A.E., Taylor, P.N., and Summons, R.E., 2012, Geochemical evidence for an Early Cambrian origin of the "Q" oils and some condensates from north Oman: Organic Geochemistry, v. 45, p. 77-90.

GrotZinger, J., AND AL-RAWAHI, Z., 2014, Depositional facies and platform architecture of microbialite-dominated carbonate reservoirs, Ediacaran-Cambrian Ara group, sultanate of Oman: American Association of Petroleum Geologists, Bulletin, v. 98, p. 1453-1494, doi: $10.1306 / 02271412063$

Le Guerroué, E., Allen, P.A., And Cozzi, A., 2006, Chemostratigraphic and sedimentological framework of the largest negative carbon isotopic excursion in earth history: the Neoproterozoic Shuram Formation (Nafun Group, Oman): Precambrian Research, v. 146, p. 68-92, doi: 10.1016/j.precamres.2006.01.007.

Henkes, G.A., Passey, B.H., Wanamaker, A.D., Grossman, E.L., Ambrose, W.G., and Carroll, M.L., 2013, Carbonate clumped isotope compositions of modern marine mollusk and brachiopod shells: Geochimica et Cosmochimica Acta, v. 106, p. 307-325, doi: 10.1016/j.gca.2012.12.020

Henkes, G.A., Passey, B.H., Grossman, E.L., Shenton, B.J., Perez-Huerta, A., and YANCEY, T.E., 2014, Temperature limits for preservation of primary calcite clumped isotope paleotemperatures: Geochimica et Cosmochimica Acta, v. 139, p. 362-382, doi: 10.1016/j.gca.2014.04.040

Henkes, G.A., Passey, B.H., Grossman, E.L., Shenton, B.J., Yancey, T.E., and PérezHuerta, A., 2018, Temperature evolution and the oxygen isotope composition of Phanerozoic oceans from carbonate clumped isotope thermometry: Earth and Planetary Science Letters, v. 490, p. 40-50, doi: 10.1016/J.EPSL.2018.02.001.

Heydari, E., AND Wade, W.J., 2002, Massive recrystallization of low-Mg calcite at high temperatures in hydrocarbon source rocks: implications for organic acids as factors in diagenesis: American Association of Petroleum Geologists, Bulletin, v. 86, p. 12851303

Hodel, F., Macouin, M., Trindade, R.I.F., Triantafyllou, A., Ganne, J., Chavagnac, V., Berger, J., Rospabé, M., Destrigneville, C., Carlut, J., Ennih, N., and Agrinier, P., 2018, Fossil black smoker yields oxygen isotopic composition of Neoproterozoic seawater: Nature Communications, v. 9, p. 1453, doi: 10.1038/s41467-018-03890-w.

HoritA, J., 2014, Oxygen and carbon isotope fractionation in the system dolomite-water$\mathrm{CO}_{2}$ to elevated temperatures: Geochimica et Cosmochimica Acta, v. 129, p. 111-124 doi: 10.1016/j.gca.2013.12.027.

Huber, M., And SloAn, L.C., 2001, Heat transport, deep waters, and thermal gradients: coupled simulation of an Eocene greenhouse climate: Geophysical Research Letters, v. 28, p. 3481-3484, doi: 10.1029/2001GL012943.

Huntington, K.W., Eiler, J.M., Affek, H.P., Guo, W., Bonifacie, M., Yeung, L.Y., Thiagarajan, N., Passey, B., Tripati, A., Daeron, M., and Came, R., 2009, Methods and limitations of "clumped" $\mathrm{CO}_{2}$ isotope $\left(\Delta_{47}\right)$ analysis by gas-source isotope ratiomass spectrometry: Journal of Mass Spectrometry, v. 44, p. 1318-1329, doi: 10.1002/jms.161 4.

JAFFrÉs, J.B.D., Shields, G.A., AND Wallmann, K., 2007, The oxygen isotope evolution of seawater: a critical review of a long-standing controversy and an improved geological water cycle model for the past 3.4 billion years: Earth-Science Reviews, v. 83, p. 83-122, doi: 10.1016/j.earscirev.2007.04.002.

John, C.M., AND Bowen, D., 2016, Community software for challenging isotope analysis: first applications of "Easotope" to clumped isotopes: Rapid Communications in Mass Spectrometry, v. 30, p. 2285-2300, doi: $10.1002 / \mathrm{rcm} .7720$

Kasting, J.F., Howard, M.T., Wallmann, K., Veizer, J., Shields, G., and Jaffrés, J.B.D., 2006, Paleoclimates, ocean depth, and the oxygen isotopic composition of seawater: Earth and Planetary Science Letters, v. 252, p. 82-93, doi: 10.1016/j.eps1.2006.09.029. Kele, S., Breitenbach, S.F.M., Capezzuoli, E., Meckler, A.N., Ziegler, M., Millan, I.M., Kluge, T., Deák, J., Hanselmann, K., John, C.M., Yan, H., Liu, Z., and Bernasconi, S.M., 2015, Temperature dependence of oxygen- and clumped-isotope fractionation in carbonates: a study of travertines and tufas in the $6-95^{\circ} \mathrm{C}$ temperature range: Geochimica et Cosmochimica Acta, v. 168, p. 172-192, doi: 10.1016/j.gca.2015.06.032

Kelson, J.R., Huntington, K.W., Schauer, A.J., Saenger, C., and Lechler, A.R., 2017, Toward a universal carbonate clumped isotope calibration: diverse synthesis and preparatory methods suggest a single temperature relationship: Geochimica et Cosmochimica Acta, v. 197, p. 104-131, doi: 10.1016/j.gca.2016.10.010.

KIM, S.-T., AND O'NEIL, J.R., 1997, Equilibrium and nonequilibrium oxygen isotope effects in synthetic carbonates: Geochimica et Cosmochimica Acta, v. 61, p. 3461-3475, doi: 10.1016/S0016-7037(97)00169-5

Knauth, L.P., 2005, Temperature and salinity history of the Precambrian ocean: implications for the course of microbial evolution: Palaeogeography, Palaeoclimatology, Palaeoecology, v. 219, p. 53-69, doi: 10.1016/j.palaeo.2004.10.014.

Knauth, L.P., AND Lowe, D.R., 2003, High Archean climatic temperature inferred from oxygen isotope geochemistry of cherts in the $3.5 \mathrm{Ga}$ Swaziland Supergroup, South Africa: Geological Society of America, Bulletin, v. 115, p. 566-580, doi: 10.1130/00167606(2003) $115<0566$ :HACTIF $>2.0$. CO;2.

Koenrer, B., Zeller, M., Aigner, T., Poeppelreiter, M., Milroy, P., Forke, H., And AlKINDI, S., 2010, Facies and stratigraphic framework of a Khuff outcrop equivalent: Saiq and Mahil formations, Al Jabal al-Akhdar, Sultanate of Oman: GeoArabia, v. 15, p. 91156

Koehrer, B., Aigner, T., And Poppelreiter, M., 2011, Field-scale geometries of Upper Khuff reservoir geobodies in an outcrop analogue (Oman Mountains, Sultanate of Oman): Petroleum Geoscience, v. 17, p. 3-16, doi: 10.1144/1354-079310-009.

Lear, C.H., 2000, Cenozoic Deep-Sea Temperatures and Global Ice Volumes from $\mathrm{Mg} / \mathrm{Ca}$ in Benthic Foraminiferal Calcite: Science, v. 287, p. 269-272, doi: 10.1126/science.287. 5451.269 .

Lloyd, M.K., Eiler, J.M., And NabeleK, P.I., 2017, Clumped isotope thermometry of calcite and dolomite in a contact metamorphic environment: Geochimica et Cosmochimica Acta, v. 197, p. 323-344, doi: 10.1016/j.gca.2016.10.037.

Love, G.D., Grosjean, E., Stalvies, C., Fike, D.A., Grotzinger, J.P., Bradley, A.S., Kelly, A.E., Bhatia, M., Meredith, W., Snape, C.E., Bowring, S.A., Condon, D.J., and Summons, R.E., 2009, Fossil steroids record the appearance of Demospongiae during the Cryogenian period: Nature, v. 457, p. 718-721, doi: 10.1038/nature07673.

Lunt, D.J., Jones, T.D., Heinemann, M., Huber, M., LeGrande, A., Winguth, A., Loptson, C., Marotzke, J., Roberts, C.D., Tindall, J., Valdes, P., and Winguth, C., 2012, A model-data comparison for a multi-model ensemble of early Eocene atmosphere-ocean 
simulations: EoMIP, Climate of the Past, v. 8, p. 1717-1736, doi: 10.5194/cp-8-171 7-2012.

Mattes, B.W., And Morris, S.C., 1990, Carbonate/evaporite deposition in the Late Precambrian-Early Cambrian Ara Formation of Southern Oman, in Robertson, A.H.F., Searle, M.P., and Ries, A.C., eds., The Geology and Tectonics of the Oman Region: Geological Society of London, Special Publication 49, p. 617-636.

Matthews, A., AND KATZ, A., 1977, Oxygen isotope fractionation during the dolomitization of calcium carbonate, Geochimica et Cosmochimica Acta, v. 41, p. 1431-1438, doi: 10.1016/0016-7037(77)90249-6.

McCarron, M.E.G., 1999, The Sedimentology and Chemostratigraphy of the Nafun Group, Huqf Supergroup, Oman [PhD Thesis]: Oxford University, $362 \mathrm{p}$.

Mettraux, M., Homewood, P.W., Al Balushi, S., Erthal, M., and Matsuda, M., 2014 Neoproterozoic microbialites in outcrops of the Qarn Alam Salt Dome, Central Oman GeoArabia, v. 19, p. 17-76.

Mettraux, M., Homewood, P., Dos Anjos, C., Erthal, M., Lima, R., Matsuda, N., Souza, A., AND Al Balushi, S., 2015, Microbial communities and their primary to early diagenetic mineral phases: the record from Neoproterozoic microbialites of Qarn Alam, Oman, in Lawson, M., Formolo, M.J., and Eiler, J.M., eds., From Source to Seep: Geochemical Applications in Hydrocarbon Systems: Geological Society of London, Special Publication 418, p. 123-154, doi: 10.1144/SP418.5.

Müller, I.A., Fernandez, A., Radke, J., van Dijk, J., Bowen, D., Schwieters, J., And Bernasconi, S.M., 2017a, Carbonate clumped isotope analyses with the long-integration dual-inlet (LIDI) workflow: scratching at the lower sample weight boundaries: Rapid Communications in Mass Spectrometry, v. 31, p. 1057-1066, doi: 10.1002/rcm.7878.

Müller, I.A., Violay, M.E.S., Storck, J.-C., Fernandez, A., van DijK, J., Madonna, C., and Bernasconi, S.M., 2017b, Clumped isotope fractionation during phosphoric acid digestion of carbonates at $70^{\circ} \mathrm{C}$ : Chemical Geology, v. 449 , p. $1-14$, doi: $10.1016 / \mathrm{j}$. chemgeo.2016.11.030.

Murray, S.T., Arienzo, M.M., and Swart, P.K., 2016, Determining the $\Delta_{47}$ acid fractionation in dolomites: Geochimica et Cosmochimica Acta, v. 174, p. 42-53, doi: 10.1016/j.gca.2015.10.029.

Murray, S.T., and Swart, P.K., 2017, Evaluating formation fluid models and calibrations using clumped isotope paleothermometry on Bahamian dolomites: Geochimica et Cosmochimica Acta, v. 206, p. 73-93, doi: 10.1016/j.gca.2017.02.021.

Obermaier, M., Ritzmann, N., And Aigner, T., 2015, Multi-level stratigraphic heterogeneities in a Triassic shoal grainstone, Oman Mountains, Sultanate of Oman: Layer-cake or shingles?: GeoArabia, v. 20, p. 115-142.

Osburn, M., Grotzinger, J., And Bergmann, K., 2014, Facies, stratigraphy, and evolution of a middle Ediacaran carbonate ramp: Khufai Formation, Sultanate of Oman: American Association of Petroleum Geologists, Bulletin, v. 98, p. 1631-1667.

Passey, B.H., And Henkes, G.A., 2012, Carbonate clumped isotope bond reordering and geospeedometry: Earth and Planetary Science Letters, v. 351-352, p. 223-236, doi 10.1016/j.eps1.2012.07.021.

Passey, B.H., Levin, N.E., Cerling, T.E., Brown, F.H., Eiler, J.M., and Turekian, K.K., 2010, High-temperature environments of human evolution in East Africa based on bond ordering in paleosol carbonates: Proceedings of the National Academy of Sciences [USA], v. 107, p. 11245-11249, doi: 10.1073/pnas.1001824107.

Prokoph, A., Shields, G.A., And Veizer, J., 2008, Compilation and time-series analysis of a marine carbonate $\delta^{18} \mathrm{O}, \delta^{13} \mathrm{C},{ }^{87} \mathrm{Sr} /{ }^{86} \mathrm{Sr}$ and $\delta^{34} \mathrm{~S}$ database through Earth history: EarthScience Reviews, v. 87, p. 113-133, doi: 10.1016/j.earscirev.2007.12.003.

Quade, J., Eiler, J., DaËron, M., And Achyuthan, H., 2013, The clumped isotope geothermometer in soil and paleosol carbonate: Geochimica et Cosmochimica Acta, v 105, p. 92-107, doi: 10.1016/j.gca.2012.11.031.

Reuning, L., Schoenherr, J., Heimann, A., Urai, J.L., Littke, R., Kukla, P.A., and Rawahi, Z., 2009, Constraints on the diagenesis, stratigraphy and internal dynamics of the surface-piercing salt domes in the Ghaba Salt Basin (Oman): a comparison to the Ara Group in the South Oman Salt Basin: GeoArabia, v. 14, p. 83-120, doi: 10.1017/ CBO9781107415324.004.

Ries, A.C., and Shackleton, R.M., 1990, Structures in the Huqf-Haushi Uplift, eas Central Oman, in Robertson, A.H.F., Searle, M.P., and Ries, A.C., eds., The Geology and Tectonics of the Oman Region: Geological Society of London, Special Publication 49, p. 653-663.

Robert, F., And Chaussidon, M., 2006, A palaeotemperature curve for the Precambrian oceans based on silicon isotopes in cherts: Nature, v. 443, p. 969-972, doi: 10.1038/ nature 05239 .

Rosenbaum, J., AND ShePpard, S.M.F., 1986, An isotopic study of siderites, dolomites and ankerites at high temperatures: Geochimica et Cosmochimica Acta, v. 50, p. 1147-1150.

Schauer, A.J., Kelson, J., Saenger, C., And Huntington, K.W., 2016, Choice of ${ }^{17}$ O correction affects clumped isotope $\left(\Delta_{47}\right)$ values of $\mathrm{CO}_{2}$ measured with mass spectrometry: Rapid Communications in Mass Spectrometry, v. 30, p. 2607-2616, doi: 10.1002/rcm.7743.

Schindelin, J., Arganda-Carreras, I., Frise, E., Kaynig, V., And Longair, M., et al., 2012, Fiji: an open-source platform for biological-image analysis: Nature Methods, v. 9, p. 676-682.

Schlaich, M., Obermaier, M., Bendias, D., And Aigner, T., 2017, Integrated stratigraphy of Triassic and Jurassic formations in the Central Oman Mountains: a synopsis: Stratigraphy and Timescales, v. 2, p. 411-436, doi: 10.1016/BS.SATS.2017.07.004.

Schoenherr, J., Littke, R., Urai, J.L., Kukla, P.A., and Rawahi, Z., 2007, Polyphase thermal evolution in the Infra-Cambrian Ara Group (South Oman Salt Basin) as deduced by maturity of solid reservoir bitumen: Organic Geochemistry, v. 38, p. 1293-1318, doi: 10.1016/j.orggeochem.2007.03.010.

Schröder, S., Schreiber, B.C.C., Amthor, J.E., and Matter, A., 2004, Stratigraphy and environmental conditions of the terminal Neoproterozoic-Cambrian Period in Oman: evidence from sulphur isotopes: Geological Society of London, Journal, v. 161, p. 489499, doi: 10.1144/0016-764902-062.

SchröDer, S., Grotzinger, J.P., Amthor, J.E., And Matter, A., 2005, Carbonate deposition and hydrocarbon reservoir development at the Precambrian-Cambrian boundary: the Ara Group in South Oman: Sedimentary Geology, v. 180, p. 1-28, doi: 10.1016/j.sedgeo.200 5.07.002.

SEEWALD, J.S., 2003, Organic-inorganic interactions in petroleum-producing sedimentary basins: Nature, v. 426, p. 327-333, doi: 10.1038/nature02132.

Shields, G., AND Veizer, J., 2002, The Precambrian marine carbonate isotope database: version 1.1: Geochemistry Geophysics Geosystems, v. 3, p. 1-12, doi: 10.1029/2001 GC000266.

StolPer, D.A., AND EILER, J.M., 2015, The kinetics of solid-state isotope-exchange reactions for clumped isotopes: a study of inorganic calcites and apatites from natural and experimental samples: American Journal of Science, v. 315, p. 363-411, doi: 10.2 475/05.2015.01.

Swart, P.K., Burns, S.J., And Leder, J.J., 1991, Fractionation of the stable isotopes of oxygen and carbon in carbon dioxide during the reaction of calcite with phosphoric acid as a function of temperature and technique: Chemical Geology: Isotope Geoscience Section, v. 86, p. 89-96, doi: 10.1016/0168-9622(91)90055-2.

Tang, J., Dietzel, M., Fernandez, A., Tripati, A.K., And Rosenheim, B.E., 2014, Evaluation of kinetic effects on clumped isotope fractionation $\left(\Delta_{47}\right)$ during inorganic calcite precipitation: Geochimica et Cosmochimica Acta, v. 134, p. 120-136, doi: 10.1016/j. gca.2014.03.005.

Tennant, C.B.B., AND Berger, R.W.W., 1956, X-ray determination of dolomite-calcite ratio of a carbonate rock: American Mineralogist, v. 42, p. 23-29.

Upchurch, G.R., Kiehl, J., Shields, C., Scherer, J., And Scotese, C., 2015, Latitudinal temperature gradients and high-latitude temperatures during the latest Cretaceous: congruence of geologic data and climate models: Geology, v. 43, p. 683-686, doi: $10.1130 / \mathrm{G} 36802.1$.

UREY, H.C., 1947, The thermodynamic properties of isotopic substances: Journal of the Chemical Society (Resumed), p. 562, doi: 10.1039/jr9470000562.

Vasconcelos, C., McKenzie, J.A., And Warthmann, R., 2005, Calibration of the $\delta^{18}$ O paleothermometer for dolomite precipitated in microbial cultures and natural environments: Geology, v. 33, p. 317-320.

Veizer, J., And Prokoph, A., 2015, Temperatures and oxygen isotopic composition of Phanerozoic oceans: Earth-Science Reviews, v. 146, p. 92-104, doi: 10.1016/j.ear scirev.2015.03.008.

VISSER, W., 1991, Burial and thermal history of Proterozoic source rocks in Oman: Precambrian Research, v. 54, p. 15-36.

WaCker, U., Fiebig, J., AND SCHOENe, B.R., 2013, Clumped isotope analysis of carbonates: comparison of two different acid digestion techniques, Rapid Communications in Mass Spectrometry, v. 27, p. 1631-42, doi: 10.1002/rcm.6609.

Wacker, U., Fiebig, J., Tödter, J., Schöne, B.R., Bahr, A., Friedrich, O., Tütken, T., Gischler, E., AND JoAChimski, M.M., 2014, Empirical calibration of the clumped isotope paleothermometer using calcites of various origins: Geochimica et Cosmochimica Acta, v. 141, p. 127-144, doi: 10.1016/j.gca.2014.06.004.

Wacker, U., Rutz, T., Löffler, N., Conrad, A.C., TütKen, T., Böttcher, M.E., And Fiebig, J., 2016, Clumped isotope thermometry of carbonate-bearing apatite: revised sample pretreatment, acid digestion, and temperature calibration: Chemical Geology, v. 443, p. $97-$ 110, doi: 10.1016/j.chemgeo.2016.09.009.

Winkelstern, I.Z., AND Lohmann, KC., 2016, Shallow burial alteration of dolomite and limestone clumped isotope geochemistry: Geology, v. 44, doi: 10.1130/G37809.1.

Received 12 November 2017; accepted 7 June 2018. 